\begin{abstract}
UNIVERSIDADE DE SÃO PAULO - USP
FACULDADE DE FILOSOFIA, LETRAS E CIÊNCIAS HUMANAS DEPARTAMENTO DE LETRAS CLÁSSICAS E VERNÁCULAS

PROGRAMA DE ESTUDOS COMPARADOS DE LITERATURAS DE LÍNGUA PORTUGUESA
\end{abstract}

AMANDA NASCIMENTO FERNANDES

O intelectual de Edward Said em Memórias do cárcere de Graciliano Ramos

Versão corrigida

São Paulo 


\author{
UNIVERSIDADE DE SÃO PAULO - USP \\ FACULDADE DE FILOSOFIA, LETRAS E CIÊNCIAS HUMANAS \\ DEPARTAMENTO DE LETRAS CLÁSSICAS E VERNÁCULAS \\ PROGRAMA DE ESTUDOS COMPARADOS DE LITERATURAS DE LÍNGUA \\ PORTUGUESA
}

\title{
O intelectual de Edward Said em Memórias do cárcere de Graciliano Ramos
}

Amanda Nascimento Fernandes

\begin{abstract}
Dissertação de mestrado apresentada ao Programa de Pós-graduação em Estudos Comparados de Literaturas de Língua Portuguesa do Departamento de Letras Clássicas e Vernáculas da Faculdade de Filosofia, Letras e Ciências Humanas da Universidade de São Paulo, para a obtenção do título de Mestre em Estudos Comparados de Literaturas de Língua Portuguesa.

Orientador: Profa. Drª. Fabiana Buitor Carelli
\end{abstract}

De acordo,

Versão Corrigida

São Paulo 
Autorizo a reprodução e divulgação total ou parcial deste trabalho, por qualquer meio convencional ou eletrônico, para fins de estudo e pesquisa, desde que citada a fonte.

\author{
Catalogação da Publicação \\ Serviço de Biblioteca e Documentação
}

Faculdade de Filosofia, Letras e Ciências Humanas da Universidade de São Paulo

Fernandes, Amanda Nascimento.

O intelectual de Edward Said em Memórias do cárcere de Graciliano Ramos / Amanda Nascimento Fernandes; orientadora Fabiana Buitor Carelli. - São Paulo, 2015.

$108 \mathrm{f}$. : il.

Dissertação (Mestrado) - Faculdade de Filosofia, Letras e Ciências Humanas da Universidade de São Paulo. Departamento de Letras Clássicas e Vernáculas. Área de concentração: Literatura Comparada.

1. Intelectual. 2. Edward Said. 3. Memórias do cárcere. I. Carelli, Fabiana. II. Título. III. Título: O intelectual de Edward Said em Memórias do cárcere em Graciliano Ramos. 
Fernandes, Amanda Nascimento. O intelectual de Edward Said em Memórias do cárcere de Graciliano Ramos. São Paulo: Universidade de São Paulo, 2015. Dissertação (mestrado). Faculdade de Filosofia, Letras e Ciências Humanas. Universidade de São Paulo, São Paulo, 2015.

Dissertação de Mestrado apresentada ao Programa de Pós-Graduação em Estudos Comparados de Literaturas de Língua Portuguesa do Departamento de Letras Clássicas e Vernáculas da Faculdade de Filosofia, Letras e Ciências Humanas da Universidade de São Paulo, para obtenção do título de Mestre em Estudos Comparados de Literaturas de Língua Portuguesa.

BANCA EXAMINADORA

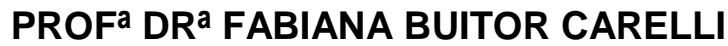

(FFLCH-USP - PRESIDENTE)

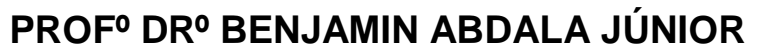

(FFLCH-USP)

PROFㅇ DRo THIAGO MIO SALLA

(ECA - USP) 
A Deus,

Aos meus pais. 
Agradeço a Deus pela força e inspiração que me iluminaram nos momentos mais difíceis quando tudo parecia escuro e impossível de se realizar.

Agradeço aos meus pais que sempre se esforçaram e me apoiaram para que eu tivesse o melhor estudo. Agradeço à minha mãe, Lúcia, pelas orações incessantes e por sempre estar disponível. Agradeço ao meu pai, Paulo, que sempre acreditou em mim e me livra dos meus apuros financeiros. Agradeço também ao meu irmão, Fábio, pelas risadas e momentos em família.

Agradeço à minha orientadora, Professora Doutora Fabiana Buitor Carelli, pela forma carinhosa com que conduziu esse trabalho, pela indicação de leituras e por ser uma pessoa tão generosa e paciente.

Agradeço aos professores Benjamin Abdala Júnior e Helder Garmes pela participação na qualificação desta dissertação. Suas considerações foram de extrema importância.

Agradeço aos professores pelos quais as disciplinas pude fazer durante o andamento desse trabalho. Professora Rejane Vecchia, Professora Ana Paula Pacheco e Professor Benjamin Abdala Júnior, obrigada.

Agradeço às minhas coordenadoras e todos os outros professores que trabalham comigo no Colégio Sagrado Coração de Jesus. Obrigada pela palavra amiga, pela paciência, compreensão e liberação para que eu pudesse participar das aulas e reuniões. 
Agradeço aos meus alunos pela compreensão e paciência que tiveram comigo durante esses anos. Agradeço também pelas palavras de incentivo e carinho.

Agradeço às minhas amigas que sempre estiveram presentes na minha caminhada. Bruna e Mayara, obrigada pela companhia maravilhosa durante as viagens a São Paulo. Obrigada pelo apoio e compreensão. Bruna, obrigada pela revisão deste trabalho. Agradeço também à minha amiga Patrícia Dias que sempre acreditou em mim e suas palavras e orações foram essenciais. 
Comovo-me em excesso, por natureza, e por ofício, acho medonho alguém viver sem paixões.

Graciliano Ramos 


\section{RESUMO}

FERNANDES, A. N. O intelectual de Edward Said em Memórias do Cárcere de Graciliano Ramos. 108 f. Dissertação (Mestrado) - Faculdade de Filosofia, Letras e Ciências Humanas. Universidade de São Paulo, São Paulo, 2015.

Este trabalho tem por finalidade apresentar os resultados da simetria entre 0 intelectual exposto por Edward Said na obra Memórias do Cárcere de Graciliano Ramos. O papel do intelectual na sociedade sempre foi alvo de questionamentos e Edward Said apresentou um modelo moderno e engajado dessa classe, que tem como missão principal representar os mais oprimidos. A importância deste trabalho se dá pela tentativa de encontrar e descrever a correspondência que existe entre as ideias de Edward Said e a conduta de Graciliano Ramos no período em que esteve preso e após a prisão também. $O$ objetivo é traçar e entender quem é a figura que Said marca como intelectual engajado e moderno capaz de compreender os problemas sociais e, por meio de suas ideias, tentar amenizá-los, destacando as reais dificuldades que atingem as sociedades carentes. Além disso, por meio do entendimento do indivíduo exposto como intelectual por Said, apresentar os comportamentos de Graciliano Ramos em Memórias do Cárcere que os liga a esse intelectual. A hipótese é que, mesmo em situações diferentes, Edward Said e Graciliano Ramos apresentam pontos em comum e, a partir de suas ideias, conseguem dar voz aos que the cercam de alguma forma, mantendo seus princípios e não se deixando influenciar por fatores que não correspondem a seus ideais.

Palavras-Chave: intelectual; Edward Said; Memórias do Cárcere. 


\section{ABSTRACT}

FERNANDES, A. N. The intellectual from Edward Said in Memories of prison by Graciliano Ramos. 108 f. Dissertação (Mestrado) - Faculdade de Filosofia, Letras e Ciências Humanas. Universidade de São Paulo, São Paulo, 2015.

This study aims to present the results of symmetry between the intellectual exposed by Edward Said in the work Memories of prison by Graciliano Ramos. The role of the intellectual in society has always been open to question and Edward Said presented a modern model and engaged of this class, whose main mission is to represent the most oppressed. The significance of this study is by trying to find and describe the harmony that exists between the ideas of Edward Said and the conduct of Graciliano Ramos in the period when he was arrested and after arrest as well. The objective is to outline and understand who is the figure that Said mark as engaged intellectual and modern able to understand social problems and, through their ideas, trying to ease them, highlighting the real difficulties that affect the poor societies. In addition, through understanding of the exposed individual as an intellectual by Said, present the behaviors of Graciliano Ramos in Memories of prison that connects them to this intellectual. The hypothesis is that, even in different situations, Edward Said and Graciliano Ramos have points in common and, from their ideas, can give voice to those around their in any way, maintaining their principles and not letting influenced by factors that do not correspond to their ideals.

Keywords: intellectual; Edward Said; Memories of Prison. 
APRESENTAÇÃO - INTELECTUALIDADE E MILITÂNCIA …...................12

CAPÍTULO I - O EMPAREDAMENTO CONCRETO ..................................38

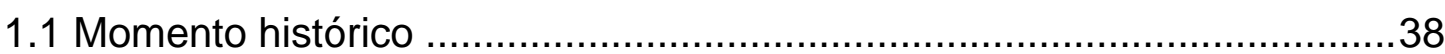

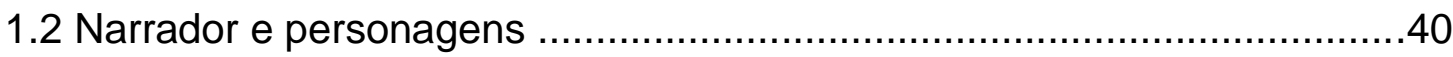

CAPÍTULO II - O EMPAREDAMENTO SIMBÓLICO (A ESCRITA) .............70

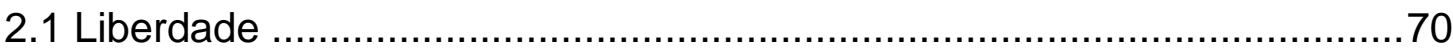

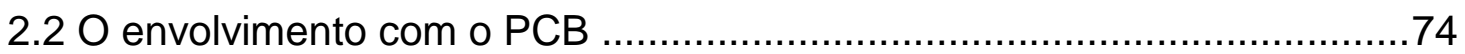

2.3 Memórias do cárcere - a escrita. .....................................................77

CAPÍTULO III

ANÁlise - A SIMETRIA ENTRE O INTELECTUAL PROPOSTO POR EDWARD SAID E O INTELECTUAL APRESENTADO POR GRACILIANO

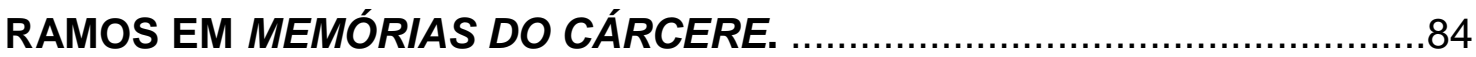

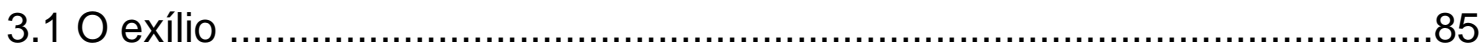

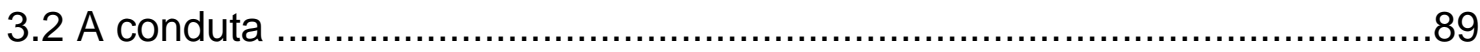

3.2.1 A vida e o engajamento como reflexos na obra literária ...............90

3.2.2 A escrita como forma de sobrevivência ......................................91

3.2.3 A liberdade da atividade intelectual .........................................96

3.2.4 A flexibilidade como busca do conhecimento .............................99

CONCLUSÃO

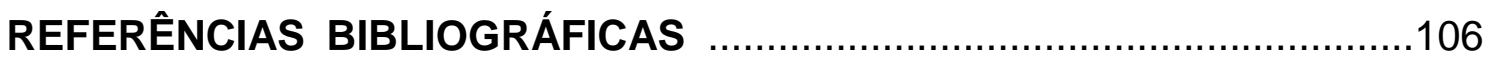




\section{APRESENTAÇÃO \\ INTELECUALIDADE E MILITÂNCIA}

Falar da categoria intelectual é complexo, visto que, ao mesmo tempo em que ela abrange praticamente todos os setores de uma sociedade, restringe-se a poucas pessoas que realmente praticam a função intelectual. Gramsci esclareceu bem isso, quando citou que todos os homens são intelectuais, mas nem todos exercem a função de intelectuais (GRAMSCI, 1982, p. 7).

O século $\mathrm{XX}$ foi marcado por indivíduos que representaram muito bem essa categoria no cenário mundial, os quais permitiram que o nome "intelectual", juntamente com sua significação, ganhasse estabilidade e credibilidade nos setores social e político contemporâneos. Para que a questão intelectual possa ser compreendida, é necessário explanar de que forma e por que esse termo surgiu, para que se possa entender o sentido que ele tem nos dias atuais.

$\mathrm{Na}$ Europa, mais precisamente na França - de acordo com a historiografia francesa - a repercussão do caso Dreyfus ${ }^{1}$ (Affaire Dreyfus), provavelmente, foi um dos fatos que marcou o início da categoria "intelectual".

Em 1894, Alfred Dreyfus, capitão judeu do exército francês, foi condenado à prisão perpétua suspeito de espionagem a favor dos alemães. Quatro anos mais tarde, a inocência de Dreyfus foi confirmada, porém sua sentença não foi reavaliada. Isso causou indignação em escritores, filósofos e artistas de modo geral.

Émile Zola, célebre escritor francês, foi um dos que mais lutaram em defesa dos direitos e pela libertação de Dreyfus. No auge da repercussão, Zola publicou o caso no jornal L'Aurore, em 1898, tornando o escândalo público e

\footnotetext{
${ }^{1}>$

http://www.snh2011.anpuh.org/resources/anais/14/1300678146 ARQUIVO ComunicacaoAnpuh2011. pdf $<$ Acesso em: 28\04\2015.
} 
balançando os alicerces do governo francês. Com isso, o escritor sofreu perseguições e, em 1902, faleceu em sua casa em Paris, provavelmente vítima de um homicídio.

Durante o caso Dreyfus, a palavra "intelectual" passou a ser usada como uma característica daqueles que estavam em defesa do capitão judeu, mas com um sentido depreciativo, como se essas pessoas não estivessem em sã consciência do que estavam fazendo, e foi vista também como um alerta para que filósofos, escritores e artistas não se misturassem com assuntos políticos, os quais não pertenciam às responsabilidades exercidas por eles.

Christophe Charle, historiador francês, define bem esse momento quando explica que "os intelectuais reivindicaram um poder simbólico e uma identidade coletiva sancionados pela aparição de um novo termo" (CHARLE, 2003, p. 142), que foi o "intelectual".

Dessa forma, a categoria intelectual passou a ser vista como um grupo que dá início a pensamentos e decisões em relação a causas que não estão inseridas em seus encargos tradicionais, mas que estão presentes em uma coletividade, à espera de cabeças pensantes que possam representar uma sociedade, principalmente aquelas que não têm voz perante as Constituições.

Assim, os intelectuais partem do princípio de caminhar defendendo uma concepção de mundo ou regimes políticos, partindo do pensamento e análise para que a ação possa se estabelecer em favor das preocupações cidadãs. Mas isso só acontece porque os intelectuais são moldados a partir de uma definição social e histórica, a qual será esclarecida posteriormente com os apontamentos de Antonio Gramsci e Edward Said. Norberto Bobbio, filósofo político e historiador político italiano, esclarece objetivamente a função intelectual, junto ao poder ideológico, presente nos indivíduos que desempenham esse papel perante a sociedade em que atuam.

Embora com nomes diversos, os intelectuais sempre existiram, pois sempre existiu, em todas as sociedades, ao lado do poder econômico e do poder político, o poder ideológico, que se exerce não sobre os corpos 
como o poder político, jamais separado do poder militar, não sobre a posse de bens materiais, dos quais se necessita para viver e sobreviver, como o poder econômico, mas sobre as mentes pela produção e transmissão de ideias, de símbolos, de visões de mundo, de ensinamentos práticos, mediante o uso da palavra (o poder ideológico é extremamente dependente da natureza do homem como animal falante). Toda sociedade tem os seus detentores do poder ideológico, cuja função muda de sociedade para sociedade, de época para época, cambiantes sendo também as relações, ora de contraposição ora de aliança, que eles mantêm com os demais poderes. (BOBBIO, 1997, p. 11)

O poder ideológico citado por Norberto Bobbio é explicado também por Antonio Gramsci, o qual faz uma relação muito coerente com a realidade, a fim de demonstrar os motivos pelos quais as ideologias estão e devem sempre estar ligadas às práticas do ramo intelectual. Para Gramsci², a ideologia faz parte de uma superestrutura a qual é composta pelo poder ideológico e político. Esses poderes, obviamente, estão diretamente relacionados com a estrutura social em que as classes estão inseridas. É neste cenário que nascem os intelectuais, que são moldados pelos contextos sociais e políticos em que agem.

À vista disso, o poder ideológico está relacionado também ao bloco histórico que se realiza a partir de uma situação histórica concreta sendo examinado como os sistemas culturais e constituindo-se das sociedades civis e política, formando assim a superestrutura. E, apesar de serem sociedades diferentes, elas precisam caminhar juntas, buscando meios para que os problemas relacionados ao social e ao político possam ser solucionados.

\footnotetext{
${ }^{2}$ Revista Administrativa de empresas - Waldemar S. Pedreira Filho. Disposto em: $>$ http://www.scielo.br/scielo.php?pid=S0034-75901977000100008\&script=sci_arttext $<$ Acesso em: $02 \backslash 05 \backslash 2015$.
} 
O problema é que nem sempre isso acontece, e as sociedades civis e política acabam se contrapondo em assuntos que divergem opiniões e estabelecem regras que favorecem uns, mas desfavorecem outros. É nesse momento em que os intelectuais devem atuar, tanto para defender um ponto de vista global quanto para confrontá-lo.

Portanto, é com essa mentalidade que os intelectuais engajados devem atuar em meio a uma sociedade, com postura pensante e prática. Homens com essas características buscam, mesmo que divergindo opiniões e entrando em conflito com ideias pré-formadas, amenizar, de certa forma, problemas que atingem grande parte de uma comunidade.

É nesse âmbito em que se encontra Edward Said, foco de estudo deste trabalho, juntamente com Graciliano Ramos, em que se busca por pontos comuns para que se possa interligar a intelectualidade do escritor palestino com o trabalho engajado de Ramos.

Edward Said foi um dos maiores intelectuais engajados que lutou a favor de uma causa a qual acreditava que era sua e estava inserida em suas responsabilidades sociais: a causa palestina.

Mas, para que se compreenda a intelectualidade deste homem e o campo em que ele agiu, é necessário entender os motivos pelos quais ele se tornou um homem de lutas, disposto a defender seus ideais de liberdade em favor ao seu povo.

Said nasceu em Jerusalém no dia primeiro de novembro de 1935, porém cresceu em uma pequena cidade entre o Cairo e a capital de Israel. Vindo de uma família de classe alta, teve uma educação regrada e rígida, baseada nos ensinamentos cristãos, já que seu pai se tornou cidadão americano quando foi para os Estados Unidos antes da $1^{\text {a }}$ guerra mundial.

Por isso, aos dezesseis anos, por insistência do pai, foi para as terras americanas buscar melhores condições de estudo, o que the proporcionou uma ótima formação acadêmica. Consequentemente, Said transformou-se em um 
grande professor e crítico literário, lecionou Literatura Comparada na universidade de Harvard, além de instruir também em Columbia, em Nova lorque. Edward Said teve uma vida travada em lutas sociais e políticas, principalmente ao que se relacionava à causa Palestina. Morreu aos sessenta e sete anos, vítima de Leucemia.

A carreira de Edward Said foi sólida e admirada. A eficácia de seu trabalho como homem e intelectual foi capaz de transformar muitas mentes que estavam estacionadas e conformadas com realidades incoerentes. Um exemplo disso foi sua luta constante pela libertação de seu povo, os palestinos, os quais foram sinônimos de militância e conquista para Said.

Said passou toda a sua vida no ocidente, porém nunca abandonou os princípios orientais; acreditava que, por meio deles, o mundo poderia conhecer, de fato, quem realmente os Árabes eram e o quanto eles são importantes para a cultura e a população mundial. Sendo assim, Said vivia dividido entre dois mundos desiguais: sua vida e formação ocidental e seus sentimentos em relação à vida oriental que foi interrompida na adolescência.

É por isso que Edward Said sentia-se como se estivesse no exílio, longe de sua terra, de seu povo, mas sempre se empenhando para conseguir meios de divulgar a grande riqueza que o mundo oriental possuía, uma riqueza associada ao sofrimento, ao desgaste que uma população marcada pela imposição de países ocidentais, os quais, muitas vezes, não mantinham o mínimo de respeito à dignidade desses povos.

Foi assim que Said, mesmo morando nos Estados Unidos, aderiu à causa Palestina como uma de suas principais lutas. Seu objetivo era defender a causa que propiciava os palestinos que estavam sendo massacrados e retirados de suas terras. Por isso, Said sofreu perseguições e, muitas vezes, foi tachado de hipócrita, pois, como vivia no ocidente, alguns sionistas americanos discorriam que Said não pertencia mais ao mundo palestino e, por isso, sua batalha a favor dessa causa não era coerente.

Mesmo com todos os empecilhos, Edward Said não abandonou seus objetivos de defender seu povo. Em 1977, tornou-se membro do Conselho 
Nacional Palestino e mantinha uma relação próxima com Yasser Arafat, então presidente da OLP (Organização para a Libertação da Palestina).

Said acreditava que a criação de um Estado binacional, que englobasse Judeus e Árabes, poderia solucionar os problemas que envolviam os palestinos, principalmente os relacionados à decência desse povo, o qual estava passando por situações de extrema miséria. Em 1991, Said demitiu-se do Conselho Nacional da Palestina, pois Yasser Arafat, durante a Guerra do Golfo - 1990 a 1991 - apoiou Saddam Hussein e isso provocou uma espécie de ruptura nas relações que Said mantinha com Arafat.

Apoiar Hussein significava quebrar os objetivos da organização palestina que, além de buscar por suas terras, também idealizava reconhecimento e tempos melhores para o mundo árabe e isso dependia muito de que a OLP criasse laços com organizações internacionais fortes, como os Estados Unidos. Porém, a invasão iraquiana ao Kuwait foi praticamente inaceitável e injustificável para o mundo, e esse apoio não favorecia os propósitos da organização palestina.

Em 1993, Yasser Arafat, ainda como presidente da OLP, concordou em participar de vários acordos com o governo de Israel, mediados pelos os Estados Unidos. Porém, o acordo de Paz de Oslo - como assim foi nomeado do ponto de vista de Said, não atendeu às necessidades palestinas, pois não permitiu condições favoráveis para que os palestinos voltassem para suas terras e, consequentemente, não coseguiram total controle sobre elas também.

A vida de Edward Said foi praticamente baseada nessa luta, mas, infelizmente, ele faleceu sem ver uma solução coerente e feliz ao povo palestino. Para ilustrar o quão importante e rico o mundo oriental se constituía, Edward Said escreveu, entre os anos de 1975 e 1976, Orientalismo, uma de suas maiores obras e a qual lhe deu ascensão em sua carreira como escritor e grande pensador. 
Publicado em 1978, Orientalismo - o Oriente como invenção do Ocidente - permitiu que Edward Said mostrasse ao mundo os valores que 0 mundo oriental possuía e o quão forte se manifestavam, principalmente em relação à sua cultura que, para Said, foi fundamental para que se delineasse a Europa. (SAID, 2007a, p. 28) "O Oriente ajudou a definir a Europa - ou o Ocidente - com sua imagem, ideia, personalidade, experiência contrastantes".

Para Edward Said, o mundo oriental está inserido na formação não somente da Europa, mas de todo o mundo ocidental em si. E, revelar isso, de certa forma, foi um ato corajoso de Said, já que o Orientalismo constitui-se como um grito de indignação contra o modo como a cultura oriental era vista: subalterna.

A obra permitiu que Said, como intelectual e ativista político, mostrasse como os ocidentais viam os orientais a partir de uma gigantesca pesquisa, incluindo textos do século XIX e XX, dos quais, alguns, revelaram-se como documentos oficiais. Essa análise possibilitou que Said definisse alguns conceitos que explicassem o que, de fato, significava o termo Orientalismo e como se constituía.

Said tem várias definições do que seria o Orientalismo em si e todas elas foram moldadas e determinadas de acordo com suas pesquisas e experiências. A primeira definição que Said apresenta, logo na introdução da obra, é voltada para o ramo acadêmico. Said explica que qualquer pessoa que estude, escreva ou ensine sobre o oriente é um orientalista, consequentemente, isso é fazer orientalismo (SAID, 2007a, p. 28).

Entretanto, baseado no sentido acadêmico, Said apresenta outra concepção do que seria Orientalismo e sua prática, porém de uma forma mais ampla, na qual afirma que o "Orientalismo é um estilo de pensamento fundamentado numa distinção ontológica feita entre o Oriente e o Ocidente" (SAID, 2007a, p. 29).

E ainda em uma terceira visão, Said acredita que o Orientalismo é uma espécie de organização Ocidental, a qual tem o poder de atender o Oriente, 
assim, "o Orientalismo como estilo ocidental para dominar, reestruturar e ter autoridade sobre o Oriente". (SAID, 2007a, p. 29).

Essas três visões diferenciadas que Edward Said aplica ao Orientalismo, assim como todo o conteúdo da obra, foram alvos de críticas e de contra posições em relação aos pensamentos do escritor palestino. É interessante que se conheça pontos de vistas de críticos que não apoiam essas perspectivas de Said, para que se possa entender que, mesmo sendo reprovado, Said soube fazer da própria experiência de vida um relato do que é ser um intelectual moderno e engajado.

Dentre as várias avaliações pelo mundo de Orientalismo, feitas por grandes nomes da Literatura e Filosofia, destaca-se Aijaz Ahmad - indiano e marxista- um dos mais importantes teóricos da atualidade de língua inglesa. Para Ahmad, Said foi incoerente em suas explicações iniciais acerca do que seria o Orientalismo e, para provar isso, esclarece os motivos pelos quais Said transgride nessas afirmações.

Em relação à primeira definição que Said oferece ao Orientalismo, Ahmad aponta que ela transcende os fatores acadêmicos, pois o Orientalismo não pode ser considerado como disciplina (AHMAD, 2002, p. 28) já que Said afirma que qualquer um que estude, pesquise e discorra sobre o tema, possa ser e fazer Orientalismo. Ahmad atenta para a hipótese de que, nesse sentido acadêmico, Orientalismo seria uma espécie de disciplina moderna, a qual estaria inserida em um currículo estudantil.

Para a segunda acepção de Said sobre Orientalismo, o crítico indiano argumenta que Edward Said extrapola no que se refere aos limites que esse termo pode atingir (AHMAD, 2002, p. 28). Said explica que o Orientalismo, a partir da definição acadêmica, passa a ser um estilo de pensamento baseado nas concepções do ser humano, interligadas com os limites do conhecimento humano. Sendo assim, Ahmad alega que, se o Orientalismo é um estilo de pensamento associado a questões ontológicas e epistemológicas, então não pode partir de princípios acadêmicos, pois essas questões vão além disso. Por 
isso, revela que Said é incoerente nas afirmações, pois elas partem de definições particulares do autor, e não estão baseadas em contextos concretos.

E, por último, sobre o terceiro conceito de Edward Said sobre a designação de Orientalismo, Ahmad afirma que, se o Oriente é uma invenção europeia e está definido como um "estilo de pensamento", quando foi que surgiu o discurso sobre o Orientalismo, já que Said cita Ésquilo e Dante como exemplos do estilo, porém, os menciona antes de identificar que foi o século XVIII o precursor dessa forma de pensar.

Essas avaliações que Aijaz Ahmad fez sobre as definições de Orientalismo propostas por Said mostram o quanto o escritor palestino foi audacioso ao discorrer sobre um tema que era criticado por muitos e visto como algo descabido para um cidadão americano. Ahmad também acreditava que era arriscado Said se autorrepresentar como "sujeito oriental", pois considerava as afirmações desse tipo como unilaterais e incabíveis para um homem que residia nos Estados Unidos.

Assim, Ahmad enfatiza suas diferenças com Said:

Discordo dele tão profundamente em questões tanto de teoria quanto de história que nossas respectivas compreensões do mundo - o mundo como é hoje e como foi em muitos momentos nos últimos dois mil anos mais ou menos - são irreconciliáveis, o que leva, inevitavelmente, a diferenças tão numerosas de interpretações locais e leitura local que nenhum ensaio pode nomeá-las todas. (AHMAD, 2002, p. 109)

Para Aijaz Ahmad, falar sobre as diferenças que possuía com Edward Said não era algo tão complexo, o grande problema era o sentimento de solidariedade que o crítico indiano possuía em relação a Said. O fato de Said auxiliar e defender o mundo palestino prejudicava a crítica de Ahmad.

Muito do que é esplêndido em sua obra se vincula ao fato de que ele tem tentado honrar essa origem; e ele o faz contra todas as dificuldades, no limite de sua capacidade, ultrapassando as fronteiras de sua 


\begin{abstract}
disciplina acadêmica e de sua formação intelectual original, não sob coação da profissão ou da fama, não em busca de ganho pessoal - na verdade, correndo um risco assustador. (AHMAD, 2002, p. 110)
\end{abstract}

Foi por essas razões que Said se consolidou como um intelectual engajado, capaz de ir além de seus intentos profissionais, priorizando questões que realmente fariam a diferença para as comunidades envolvidas. Isso comprova que Said honrava seu povo, pois se permitiu conviver com constantes ameaças de morte por grupos que aterrorizavam palestinos patriotas. Essa honra é vista como algo raro por Aijaz Ahmad, o que the permitiu admirar, mesmo que com inúmeras divergências de pensamento, a vida de Said.

A partir disso, Ahmad afirma que "o Orientalismo marca uma ruptura tão radical na própria carreira intelectual de Said porque a escrita desse livro foi uma tentativa de resolver qual significado tinha para ele ser um palestino que mora e ensina nos Estados Unidos" (AHMAD, 2002, p. 111). E isso fica muito explícito na introdução de Orientalismo, quando Said afirma que o conteúdo da obra é baseado em suas experiências de vida, não somente como cidadão americano, mas como palestino, que via seu povo sofrendo, em meio a problemas que, aparentemente, não tinham soluções.

As minhas próprias experiências nessas questões são parte do que me fez escrever esse livro. A vida de um árabe palestino no Ocidente, especialmente nos Estados Unidos, é desanimadora... A teia do racismo, dos estereótipos culturais, do imperialismo político e da ideologia desumanizante que contém o árabe ou 0 muçulmano é realmente muito forte, e é esta teia que cada palestino veio a sentir como seu destino singularmente punitivo. (SAID, 2007a, p. 27)

Edward Said procurou, por meio do Orientalismo, inventar o sujeito oriental que estava perdido, oculto em meio à cultura ocidental. 
Toda a minha educação, naquelas colônias (Palestina e Egito) e nos Estados Unidos, foi ocidental, e ainda assim naquela primeira consciência profunda persistiu. De muitas maneiras, o meu estudo do Orientalismo foi uma tentativa de inventariar em mim o sujeito oriental, os traços da cultura cuja dominação tem sido um fator tão poderoso na vida de todos os orientais. (SAID, 2007a, p. 57)

Contestando isso, Ahmad (2002, p. 126) afirma que o conteúdo de Orientalismo não é original, já que os documentos que Said cita e explica na obra já foram vistos, falados e utilizados, de alguma maneira, por outros escritores. E ainda afirma que o que é autentico na produção é exatamente o reflexo que a experiência de vida de Said com a arquitetura do livro traz para a obra.

Essa arquitetura do livro citada por Ahmad foi um dos fatores que contribuíram para que Said tivesse sucesso com a obra, pois ele também, como professor, pesquisou não somente documentos oficiais e textos de séculos passados, mas investigou a Literatura ocidental, mais precisamente da Europa, com o objetivo de encontrar romances, contos e textos que, de alguma forma, mostravam a visão dos ocidentais em relação ao Oriente.

Isso permitiu que Orientalismo fosse resumido como uma obra que buscou salientar o Ocidente como civilização e buscar, através dele, a visão que eles, ocidentais, possuíam do mundo oriental para inventar outra civilização no caso, o Oriente.

Desse modo, Said dividiu o livro em três partes. A primeira enfocou no espaço em que o Orientalismo está inserido, com pesquisas que mostram as questões geográficas e históricas, para que o campo de estudo fosse demarcado.

A segunda parte orientou os estudos para as questões religiosas que envolvem o mundo oriental, além de identificar as fronteiras que cercam o povo árabe. Esses dois fatores levaram Said a pesquisar e, consequentemente, discutir esses impasses dentro da obra. 
Finalmente, no terceiro segmento do livro, Edward Said discute o Orientalismo contemporâneo, dando enfoque ao Orientalismo que está subentendido e ao mesmo tempo visível.

Assim, com o conteúdo da obra, é possível afirmar que o Orientalismo conseguiu atingir seu objetivo, mostrando que, muitas vezes, o Ocidente tem uma visão distorcida do que realmente acontece no Oriente, principalmente no que diz respeito aos povos e às culturas que fazem parte do cenário oriental.

Por ser considerada uma obra complexa, a qual permitiu que Said fosse alvo de críticas, foi através de Orientalismo que Edward Said começou a esboçar o que, de fato, para ele, era um intelectual engajado, relacionando sua obra à sua experiência de vida e interligando com suas responsabilidades a causa palestina. Se o intelectual que Said incorporou atua no campo fora de sua profissão, com objetivos de interceder por causas e ideias que estão relacionados ao coletivo, ele se torna um intelectual público, alvo de críticas.

É por isso que Edward Said não apenas explanou sua intelectualidade em Orientalismo, mas em livros que vieram posteriormente, como Cultura e Imperialismo, no qual Said ainda continuou falando do Orientalismo, porém expande suas considerações para outras regiões também colonizadas como a Índia, África, entre outras.

Mas, foi em Representações do Intelectual, livro publicado após Said ministrar seis conferências - As palestras de Reith de 1993 - as quais foram transmitidas ao vivo pela emissora de televisão BBC - British Broadcasting Corporation, que Edward Said explanou o que é ser e fazer intelectualidade na modernidade. Resumindo o conteúdo da obra, Said expõe o intelectual como um ser pensante, simples e público, o qual mantém suas opiniões contra os interesses do status quo.

Edward Said não só busca esboçar o intelectual, como também fragmentar as várias vertentes que esse assume em sua forma representativa. Vertentes essas que, por vezes, contestam a própria condição de ser um intelectual, causando uma perturbação na definição do que é ser e representar um intelectivo. 
Para exemplificar esse aspecto bilateral da realidade intelectual, Said fez comparações entre o que é ser um intelectual para Antonio Gramsci e para Julien Benda, dois grandes filósofos intelectuais do século XX que apresentaram visões distintas desses indivíduos representantes da sociedade. Porém, Said enfoca e considera a visão de Gramsci mais real e mais compatível com a realidade e é por isso que, para se expor e entender o intelectual proposto por Said, é necessário, primeiro, compreender o intelectual de Antonio Gramsci.

Ainda em Orientalismo, Said cita um conceito ${ }^{3}$ de Gramsci apresentado em Cadernos do Cárcere que foi fundamental para a crítica do escritor palestino: "o ponto de partida da elaboração crítica é a consciência do que você realmente é, 'é o conhece-te a ti mesmo' como um produto do processo histórico até aquele momento, o qual depositou em você uma infinidade de traços, sem deixar um inventário".

Como discutido anteriormente, Said tinha plena consciência de quem ele era e qual era sua origem, por isso desenvolver a crítica, moldando não somente os parâmetros do termo Orientalismo, mas a estrutura disposta em um intelectual, foi uma atividade coerente e baseada em sua história. Assim, Said afirma que "muito do investimento pessoal nesse estudo deriva da minha consciência de ser um "oriental", por ter sido uma criança que cresceu em duas colônias britânicas" (SAID, 2007a, p. 57).

As relações que Said manteve com as afirmações de Antonio Gramsci não se limitam somente à visão crítica e consciente do que realmente eram. $\mathrm{A}$ história de Antonio Gramsci também reflete em sua obra, do mesmo jeito que a de Said. Gramsci nasceu na Itália em 1891, sofreu durante a infância por causa de uma doença que, de fato, só foi diagnosticada quando ele esteve preso. Essa doença o deixou corcunda, porém não o atrapalhou de brilhar como estudante e cursar o curso de Letras aos vinte e um anos.

\footnotetext{
${ }^{3}$ Antonio Gramsci - Cadernos do Cárcere - disposto em: Orientalismo de Edward Said, 2007, p. 56-57.
} 
Em 1921, Gramsci ajudou a fundar o partido Comunista Italiano, o que Ihe proporcionou a missão de ajudar a promover a integração dos partidos de esquerda em seu país. Em 1926, foi preso pela polícia fascista e recebeu sentença de vinte anos. Aos quarenta e seis anos, estava muito doente e recebeu liberdade condicional, porém, não resistiu à doença e a todo sofrimento e veio a falecer.

No período em que passou dentro do cárcere, Gramsci escreveu mais de trinta cadernos, os quais falavam do nacionalismo italiano, de teoria crítica e educacional. Esses cadernos foram publicados: "Cadernos do cárcere" e "Cartas do cárcere". Foi por meio dessas publicações que Gramsci passou a ser conhecido como um dos grandes pensadores em relação à educação. Professores o admiram por suas ideias sensatas, as quais se baseiam na mudança de mentalidade, para que as situações-problemas possam ter soluções.

Essas mudanças de mentalidade, para Gramsci, dependiam de dois fatores: dos intelectuais e da escola. A escola, para Gramsci, era vista como uma instituição capaz de conceber os intelectuais, moldando-os para que sejam da sociedade.

$$
\begin{aligned}
& \text { O desenvolvimento alcançado pela atividade e pela } \\
& \text { organização escolar nas sociedades que surgiram do } \\
& \text { mundo medieval indica a importância assumida no } \\
& \text { mundo moderno pelas categorias e funções } \\
& \text { intelectuais: assim como se buscou aprofundar e } \\
& \text { ampliar a "intelectualidade" de cada indivíduo, buscou- } \\
& \text { se igualmente multiplicar as especializações e } \\
& \text { aperfeiçoá-las. (GRAMSCI, 1982, p. 9) }
\end{aligned}
$$

Essa citação mostra quais foram os resultados das atividades realizadas pelas instituições escolares. Assim, Gramsci defendia a ideia de criação de escolas que fossem capazes de desenvolver intelectuais instruídos a manter a educação como um fator fundamental e contínuo, sendo desenvolvido juntamente com o social e o político. 
A complexidade da função intelectual nos vários Estados pode ser objetivamente medida pela quantidade das escolas especializadas e pela sua hierarquização: quanto mais extensa for a 'área' escolar e quanto mais numerosos forem os 'graus' verticais da escola, tão mais complexo será o mundo cultural, a civilização, de um determinado Estado. (GRAMSCI, 1982, p. 9)

E, a partir desses pensamentos, Gramsci esboçou o que de fato seria o intelectual modelo, capaz de pensar em resultados que fossem significativos para um coletivo.

Para Gramsci, o fato de todos os Homens serem intelectuais, mas nem todos desenvolverem esse ofício, está relacionado ao fator social, já que o homem é um ser racional e possui faculdades, mas alguns não desenvolvem o papel coletivo que 0 verdadeiro intelectual deve amplificar. Esse desenvolvimento vem de fatores que Gramsci julga fundamental em intelectuais, pois são uma mistura de técnica, trabalho, concepção humanohistórica e ciência.

Cada grupo social [...] cria para si, ao mesmo tempo, de um modo orgânico, uma ou mais camadas de intelectuais que the dão homogeneidade e consciência da própria função, não apenas no campo econômico, mas também no social e no político. (GRAMSCI, 1982, p. 3)

Sendo assim, de acordo com Gramsci, a própria sociedade cria os intelectuais para que esses consigam estabelecer uma consciência coletiva, interligando os ideais políticos com os sociais. Dessa forma, Gramsci explicou em suas obras o que é ser um intelectual capaz de organizar uma sociedade. Como já citado, esse intelectual deve 'nascer' de uma instituição escolar especializada na criação de pensadores engajados para que isso influencie em suas atividades públicas de modo sensato.

O que Gramsci critica é o fato de existir a utopia social, na qual os intelectuais confiam em sua independência, consequentemente considerando- 
se autônomos e dotados de características particulares (GRAMSCI, 1982, p. 6). Isso não está ligado ao desenvolvimento da intelectualidade proposta por Gramsci, visto que, baseada nela, o intelectual deve manter-se unido às esferas políticas e sociais, e não somente especializando-se em suas atividades, mas participando de outras que não estão inseridas em seu âmbito.

Todo homem, fora de sua profissão, desenvolve uma atividade intelectual qualquer, ou seja, é um 'filósofo', um artista, um homem de gosto, participa de uma concepção do mundo, possui uma linha consciente de conduta moral, contribui assim para manter ou para modificar uma concepção do mundo, isto é, para promover novas maneiras de pensar. (GRAMSCI, 1982, p. 7-8)

É por isso que Gramsci ainda afirma que o intelectual "deve ser um organizador de massa de homens, deve ser um organizador da confiança" (GRAMSCI, 1982, p. 3).

Para diferenciar os vários níveis de intelectualidade, Gramsci dividiu os intelectuais em dois grupos que foram nomeados como tradicionais e orgânicos. Os intelectuais tradicionais são considerados representativos, porém, imutáveis. Passam décadas desenvolvendo o mesmo trabalho e não elaboram projetos que contribuam para uma sociedade mais ativa e atualizada com o contexto atual. Esses intelectuais consideram-se como uma classe eminente da sociedade, dos quais se podem destacar o filósofo, o artista, o jornalista, o literato, entre outros.

Mesmo com essa distinção que os intelectuais tradicionais fazem de si mesmos em relação à sociedade, eles, consequentemente, esquecem que o intelectual moderno precisa igualar-se à massa para que possa organizá-la de forma coerente. E, para isso, precisam da formação técnica proposta por Gramsci, para que, junto com a sociedade, possam mudar as mentalidades e concepções de mundo que foram impostas por um sistema.

Já os orgânicos são intelectuais que buscam a expansão dos ideais dentro de uma sociedade, mantendo-se ativos e perturbadores. Assim, 
expressam as experiências e os sentimentos que a maioria não consegue expressar, executando suas tarefas tanto na sociedade cível quanto na política. Consequentemente, esses intelectuais estão ligados às necessidades das classes.

Em resumo, para Antonio Gramsci, o intelectual moderno precisa comprometer-se com causas sociais que atingem a sociedade de uma forma geral, e, consequentemente, pensar em soluções concretas e compatíveis com a realidade que cerca o meio em questão. Além disso, o novo intelectual não pode depender apenas do uso da palavra, do seu poder de persuadir, mas deve associar-se à vida prática, planejar e ser um constante convincente. $\mathrm{Na}$ verdade, o intelectual, para Gramsci, deve unir as qualidades dos intelectuais tradicionais e orgânicos.

E foi com essas considerações que Gramsci anunciou em suas obras as características que um intelectual moderno e engajado deve possuir, ou seja, as funções que esses sujeitos devem praticar para que possam contribuir com a sociedade.

O modo de ser do novo intelectual não pode mais consistir na eloquência, motor, exterior e momentâneo dos afetos e das paixões, mas num imiscuir-se ativamente na vida prática, como construtor, organizador, "persuasor permanente", já que não apenas orador puro - e superior, todavia, ao espírito matemático abstrato, da técnica trabalho, eleva-se à técnica ciência e à concepção humanista histórica, sem a qual se permanece "especialista" e não se chega a "dirigente". (GRAMSCI, 1982, p. 8)

Por meio das considerações de Antonio Gramsci, fica evidente que, não somente em Representações do intelectual, mas em toda sua obra, Edward Said esboça um reflexo do que foi a intelectualidade para Gramsci. "O que eu irei discutir nestas conferências assume como certas estas realidades do final do século XX, originalmente sugeridas por Gramsci”. (SAID, 2000, p. 28). 
Dessa forma, Said procurou estabelecer um modelo de intelectual moderno: uma figura que seja representativa, perturbadora, engajada em causas sociais e que não esteja preocupada em agradar para que possa ser aceita, pois a consequência de ser um intelectual, muitas vezes, é não ser aceito.

Edward Said delineia o intelectual simples, objetivo e capaz de incitar a sociedade a fazer mudanças, a querer o novo, mesmo se esse "novo" for perturbador e contraditório ao que a maioria pensa.

Analisar o intelectual proposto por Said é perceber que dentro de um cenário social, existem, ainda, pessoas que pensam no bem como uma forma de manter vivas as esperanças para um futuro promissor e mais recíproco. Dessa maneira, vê-se a dificuldade de manter um intelectual ativo, visto que as limitações impostas, os padrões que a sociedade é obrigada a vestir são inúmeros e inconsequentes. Assim, surge o trabalho intelectual que, geralmente, está inserido no caos, no tormento de um povo.

Da mesma maneira que em Orientalismo, as representações das características que compõem um intelectual estão claramente ligadas às experiências de vida de Said no conteúdo de Representações do intelectual: "Até os críticos bem intencionados das minhas palestras de Reith [...] partiam do princípio de que as minhas exigências sobre o papel do intelectual na sociedade continham uma mensagem autobiográfica velada" (SAID, 2000, p. $15)$.

Por ser um palestino, Said afirma que era considerado um assassino de judeus, visto como sinônimo de violência, por isso, logo no início de suas considerações, afirma que um dos principais deveres de um intelectual é destruir os estereótipos que a sociedade impõe para que as atividades intelectuais possam realmente surtir efeito e fazer com que os pensamentos não sejam reduzidos a esses rótulos que tanto impedem o crescimento social (SAID, 2000, p. 14).

Said também defendeu a ideia da exposição do intelectual, afirmando que indivíduos que prezam, defendem e executam a atividade intelectual 
devem se expor, ou seja, manter uma atuação pública para que seu trabalho possa ser visto e divulgado. Além disso, Said explica que o intelectual, como figura pública, não deve desempenhar seu trabalho de modo que esse seja esperável, e muito menos se faça submisso e aceitável aos trabalhos alheios. $\mathrm{O}$ verdadeiro intelectual não tem medo de ser reprovado. O "desempenho público não pode ser previsível nem forçado a encaixar-se num slogan, numa linha partidária ortodoxa ou num dogma estabelecido" (SAID, 2000, p. 15).

Sendo assim, o intelectual é alvo de um grande público, o qual, para Said, se torna seu eleitorado, e é por isso que o desempenho público do intelectual é um dos fatores que mais pesam na identidade intelectiva, justamente por ele representar uma sociedade. Consequentemente, essa postura diante do público não pode ser moldada de acordo com ideias préformadas e impostas, as quais permitem que os princípios do indivíduo fiquem em segundo plano.

\begin{abstract}
O que interessa é o intelectual enquanto figura representativa - alguém que visivelmente representa um qualquer ponto de vista, alguém que articula representações a um público, apesar de todo o tipo de barreira. $O$ meu argumento é que os intelectuais são indivíduos com vocação para a arte de escrever, quer se trate de falar, escrever, ensinar, ou aparecer na televisão. E essa vocação é importante na medida em que é reconhecível publicamente e envolve, em simultâneo, empenhamento e risco, arrojo e vulnerabilidade. (SAID, 2000, p. 29)
\end{abstract}

Em vista disso, Said esclarece que a conduta pública dos intelectuais escritores é mais visível, pois "a partir do momento em que as palavras são escritas e depois publicadas, entramos no mundo público" (SAID, 2000, p. 2829), assim, esses homens que manifestam a intelectualidade por meio da escrita têm a obrigação de passar a seu eleitorado o trabalho realizado de forma clara e coerente, já que o intelectual escritor tem o poder de persuadir outras pessoas a favor de seu ponto de vista. 
Entretanto, em sua obra Humanismo e Crítica democrática, a qual reúne cinco dos últimos ensaios escritos por Edward Said, há uma revisão dos conceitos do que seria um escritor público e intelectual, que amplia e diferencia a ideia de sujeito público esboçada em Representações do intelectual, em que, de um modo geral, mostra a atividade intelectual ligada à política.

A partir da década de 90 , com o avanço tecnológico e da indústria virtual, a ideia de escritor-intelectual mudou, sendo assim, Said foi obrigado a repensar em alguns conceitos de modo que o intelectual se encaixasse nos moldes modernos.

O principal fator que Said tenta resolver é a questão que leva à reflexão se é possível o escritor-intelectual ficar longe das concepções políticas, o que, de fato, os distanciam mais da coletividade. E, se puderem, Said questiona o 'como' e 'em que medida' isso pode ocorrer. Isso acontece porque o controle do que é público e político ficou sem limites, fazendo com que sucedesse uma mistura de tarefas e interesses. "Muitas pessoas ainda sentem a necessidade de ver o escritor-intelectual como alguém que deve ser escutado como guia no presente confuso e, ao mesmo tempo, também como líder de uma facção, tendência ou grupo disputando mais poder e influência" (SAID, 2007b, p. 149).

Porém, após a Guerra Fria, Said afirma que o escritor-intelectual ganhou novas configurações em relação ao seu desempenho público, visto que várias possibilidades para efetuar seu papel se abriram e, algumas estão dispostas num âmbito distante da política. Said esclarece que no mundo árabe-islâmico, há duas palavras para designar um intelectual: cultura e pensamento e, nesses dois casos, a atividade intelectual é estendida com a equivalência com o governo. Entretanto, no mundo atual, muitos regimes não apresentam mais confiança e, assim, Said afirma que:

No vácuo moral criado, por exemplo, pelos governos republicanos dinásticos como os do Egito, Iraque, Líbia ou Síria, muitas pessoas recorrem a intelectuais religiosos ou seculares (ainda predominantemente masculinos) para obter a liderança já não fornecida pela autoridade política, mesmo que os governos 
tenham tentado cooptar intelectuais autênticos como seus porta-vozes. (SAID, 2007b, p. 150)

E a partir disso, as pessoas acabam misturando os intelectuais à política, como se os dois estivessem acoplados, mas não estão. Said exemplifica que, por seu um escritor-intelectual, muitos o perguntam como os Estados Unidos devem agir sobre determinado assunto político, se deve fazer algo ou deixar de fazer, isso porque "a noção de governo se alojou no próprio coração da prática intelectual fora da universidade" (SAID, 2007b. P. 152).

Foi por esses fatores que Said precisou repensar no que realmente seria um intelectual público, se com todas essas mudanças após a década de 90 ele ainda continuaria mantendo as mesmas características intelectuais esboçadas anteriormente.

Said aponta para os discursos de alguns intelectuais contemporâneos que estão repletos de interesses políticos, e isso faz com que a prática intelectual não sustente as necessidades de uma sociedade, visto que, às vezes, são opostas às medidas que o governo impõe. Assim, para suprir a falta desses intelectuais que estão usufruindo desses interesses políticos, surgem outras formas de representação e substituição, como por exemplo, as ONG's.

\footnotetext{
Há atualmente uma rede bastante extensa de ONG's criadas para tratar das minorias e dos direitos humanos, das questões femininas e ambientais, além de movimentos pela mudança democrática e cultural, e mesmo que nada disso possa ser um substituto para a ação ou mobilização política, especialmente para protestar e tentar impedir guerras ilegais. (SAID, 2007b, p. 153).
}

Apesar de não substituírem a ação política que é necessária para um Estado, as ONG's e outras instituições acabam representando, na forma prática, a voz daqueles que se sentem submissos diante das imposições políticas que, por vezes, são descabidas e contrárias aos interesses de uma população. Sendo assim, Said afirma que o papel do escritor vem se 
encaixando cada vez mais na estrutura intelectual, visto que a ausência de indivíduos capazes de denunciar, dizer a verdade e lutar pelas preocupações sociais está criando um abismo entre a teoria intelectual e a prática.

Antigamente, os intelectuais ligados à literatura eram vistos como indivíduos "parasitas", já que não agregavam mudanças à sociedade e, na maioria das vezes, permaneciam alienados aos problemas sociais. Hoje em dia, Said afirma que os escritores estão alinhando seu papel de literatos com os objetivos intelectuais, ou seja, a literatura passou a ser uma espécie de instrumento para a denúncia e combate dos impasses que afetam uma coletividade (SAID, 2007b, p. 155).

Ademais, Said também coloca a questão de o escritor possuir um dos mais honrosos lugares, em questão de criatividade, em todas as culturas. Assim, defende a ideia da união entre os objetivos da intelectualidade moderna e engajada com o papel "especial" e importante que os escritores exercem na sociedade.

Os indivíduos ou grupos sociais, quando estão em busca de justiça social, optam por falar ou escrever, como elucida Said, em vez de permaneceram em silêncio. Muitas vezes, esses indivíduos ou grupos não conseguem adquirir a liberdade social no meio em que estão inseridos, provocando, assim, um impedimento do crescimento social e político. Dessa forma, procuram meios para que esses anseios de desenvolvimento possam ser concretizados. "O intelectual, portanto, está em posição de tornar possível e fomentar a formulação dessas experiências e desejos" (SAID, 2007b, p. 164). Nessa perspectiva, o papel dos escritores intelectuais ganha ênfase, pois conseguem associar a habilidade da escrita com a percepção subjetiva das necessidades sociais.

Para explicar o papel desse intelectual citado acima por Said, ele ressalta que esse deve "desafiar, derrotar tanto um silêncio imposto como a quietude normalizada do poder em todo e qualquer lugar e sempre que possível" (SAID, 2007b, p. 165). Pois, ao mesmo tempo em que existe um 
discurso para 'abafar' as vontades e necessidades de uma sociedade, também existe um discurso intelectual capaz de promover as mudanças desejadas.

Para mostrar a abrangência da intelectualidade engajada proposta por Said, ele esclarece que há muitas práticas que envolvem a intelectualidade, não somente a escrita em si, mas outras fontes de divulgar e lutar a favor do término do sofrimento de um indivíduo ou de um grupo e proporcionar uma voz que discorde dos fatores impostos e prejudiciais. Essas práticas são exemplificadas: o filme, a fotografia, a música e todas as artes que envolvem a escrita, e, assim, o intelectual é disposto por Said como um "vigia" que está em todos os setores da sociedade para que consiga "discernir as possibilidades de intervenção ativa, quer seja realizada por nós mesmos, quer reconhecida em outros que tomaram a iniciativa antes ou já estão em ação" (SAID, 2007b, p. $169-170)$.

Se para Said o intelectual deve fazer-se presente nos mais diversos lugares e posições sociais, esse intelectual também deve entender que nem sempre ele vai agir sozinho, que os projetos contra questões problemáticas devem ser vistos em conjunto para que esse trabalho intelectual possa ser efetivado de um modo mais amplo. Assim, Said explica quais tipos de questões-problemas devem ser trabalhadas coletivamente e cita três que são fundamentais e que merecem intervenção e elaboração de um intelectual.

A primeira questão é a luta contra o desaparecimento do passado, que vem sendo sugado pelas mudanças repentinas e por práticas repletas de interesses políticos que impedem o seguimento natural da história. Então, Said declara que "o papel do intelectual é apresentar narrativas alternativas e outras perspectivas da história que não aquelas fornecidas pelos combatentes em nome da memória oficial, da identidade nacional e da missão" (SAID, 2007b, p. 170). Visto que, geralmente, essas narrativas que traduzem e apresentam a história de um povo são voltadas para discursos que minimizam ou escondem parcial ou totalmente resquícios de problemas que não foram solucionados no passado e os quais geraram os problemas atuais. Dessa forma, é dever do intelectual agir sobre essas narrativas, avaliar e perceber que "a necessidade 
atual é de histórias desintoxicadas e sóbrias que tornem evidentes a multiplicidade e a complexidade da história" (SAID, 2007b, p. 171).

A segunda questão, para Said, que deve ser intercedida pelos intelectuais é a construção de campos que promovam a igualdade dentro das sociedades e não de campos de batalha. Said exemplifica esse problema com o processo da descolonização, o qual valoriza suas lutas pela libertação, mas não descarta que, por meio dela, também surgem opressores nacionalistas que não colaboram e não praticam a igualdade social, por mais que aquele povo esteja liberto.

Nas várias disputas a respeito da justiça e dos direitos humanos de que tantos de nós sentimos ter participado, deve haver um componente para o nosso envolvimento que enfatize a necessidade da redistribuição dos recursos e que defenda o imperativo teórico contra as imensas acumulações de poder e capital que tanto desfiguram a vida humana. A paz não pode existir sem a igualdade; esse é um valor intelectual que precisa desesperadamente de reiteração, demonstração e esforço. (SAID, 2007b, p. 171-172)

Em terceiro lugar, como mediação intelectual, Said reflete, mais uma vez, sobre a questão da Palestina, a qual se manifesta de um modo mais próximo a ele. Edward Said afirma que, com todas suas reflexões e discussões sobre o problema, ainda não conseguiu encontrar uma solução que fosse coerente tanto para os palestinos, quanto para os israelenses.

Como intelectual, Said não enxerga uma saída para essa questão que rodeie apenas as esferas geográficas, visto que não há cabimento em fazer com que Israel desocupe as terras da antiga Palestina, transformando-se, assim, em novos refugiados. "Não pode ser correto privar todo um povo de sua terra e herança. Os judeus são também o que chamei uma comunidade de sofrimento e carregam uma herança de grande tragédia" (SAID, 2007b, p. 173). 
Assim, Said esclarece que os intelectuais, por mais que não consigam enxergar possíveis soluções, como no caso da questão Palestina, devem captar o que está à sua frente, transitar em meio à realidade, por mais que essa pareça incompreensível.

É por isso que Said defende a constante 'aparição' de intelectuais engajados, pois os interesses estão maiores que a vontade de mudar, de levar o bem e de proporcionar melhores condições de vida às comunidades esquecidas e subestimadas. Por esse motivo, a classe intelectual vai desaparecendo, não no sentido literal da palavra, mas na prática e no respeito às características que determinam um ser pensante e engajado em causas sociais, assim, "a busca de intelectuais autênticos continua, bem como a luta" (SAID, 2007b, p. 150).

Não somente o escritor-intelectual, mas todos os homens que 'cumprem' as características descritas por Said para que se desenvolva a intelectualidade de forma engajada, também são vistos como intelectuais. Por isso, os intelectuais podem pertencer a qualquer tipo social, a qualquer profissão. Edward Said acredita que a função intelectual é bem mais abrangente do que o complexo papel de pensar, ela é prática, é dinâmica e se move de acordo com as necessidades sociais.

Essas necessidades sociais estão diretamente ligadas ao poder que 0 engajamento tem, não só de tentar resolver ou diminuir as carências, mas de levá-las a público, de revelar pensamentos, ideias e faltas que estão presentes em determinado meio social.

Ainda assim, para Edward Said, mesmo o intelectual possuindo a arte da representação, colocando em vista ideias, filosofias, pontos de vista para um público, além de se manter firme e coerente em seus propósitos, não se deixando influenciar por fatores externos para que agrade ao público ou represente algo que de fato não é, o intelectual também vai encontrar impasses que parecem não ter desfechos cabíveis à realidade. E, com essa situação, Said não encara como vergonhoso não descobrir, imediatamente, soluções práticas que resolvam questões-problemas. 
O segredo da questão intelectual está no equilíbrio entre o pensar e agir, além de perceber que existirão momentos em que será preciso seguir em frente, mesmo que tudo reflita uma realidade inconstante, perturbadora e inconsequente.

Concluo com o pensamento de que o lugar provisório do intelectual é o domínio de uma arte exigente, resistente, intransigente, na qual, lamentavelmente, ninguém pode se refugiar, nem buscar soluções. Mas apenas nesse exílio precário é possível compreender de fato a dificuldade do que não pode ser compreendido, e continuar a seguir em frente mesmo assim. (SAID, 2007b, p. 173)

Com essa explanação da figura intelectual exposta por Edward Said, este trabalho visa estabelecer pontos que ligam Graciliano Ramos, mais precisamente no contexto de Memórias do cárcere, às características que Said apresentou como um modelo para a representação do intelectual moderno e engajado. 


\section{Capítulo 1 - O EMPAREDAMENTO CONCRETO: MOMENTO HISTÓRICO, NARRADOR E PERSONAGENS.}

\section{1 - MOMENTO HISTÓRICO}

Historicamente, o plano governamental de Getúlio Vargas não foi sinônimo de fracasso, já que trouxe muitas mudanças e benefícios para os trabalhadores com a Constituição de 1934. Se Getúlio era o nome que o trabalhador urbano reverenciava, o homem do campo não entendia e também não enxergava os motivos de tanta euforia.

Com os direitos trabalhistas implantados, a vida melhorou e o proletariado ganhou motivos para acreditar no desenvolvimento do país, porém, um desenvolvimento totalmente voltado para as cidades, visto que a industrialização era a chave do avanço da época.

O ano de 1930 "marca o fim da hegemonia agrário-exportadora e o início da estrutura produtiva de base urbano-industrial" (OLIVEIRA, 2003, p. 31). Com isso, a economia brasileira passou por transformações, e a revisão da composição socioeconômica foi concebida por meio de uma política "mascarada" que não via mais a agricultura como forma de desenvolvimento. Assim, a atividade agrícola possuiu, na época, uma função dupla: ainda permanecia ativa, pois produzia muito, mas, ao mesmo tempo, não recebia a devida importância, já que poderia significar uma volta no tempo e impedir o desenvolvimento industrial do Brasil.

A consequência disso foi o esquecimento do sertanejo brasileiro, aquele homem do campo que fazia ligação direta com o setor agrícola. E, se a agricultura não era mais vista como ponto de desenvolvimento do Brasil, o homem do campo também não estava enquadrado na política de desenvolvimento da década de 30 .

Se "o moderno cresce e se alimenta da existência do atrasado" (OLIVEIRA, 2003, p.32), o subdesenvolvimento, assim, pode ser visto como uma espécie de nutriente para o crescimento do capitalismo. E foi exatamente 
assim que o plano de política desenvolvimentista de Vargas efetivou-se. E o nome "subdesenvolvimento" foi aplicado ao Brasil, já que (MELLO, 1963, p. 317) nenhuma mudança perceptiva que distanciava o Brasil dos países ricos foi efetivada a ponto de retirar do país o codinome de nação "atrasada".

Porém, ainda na década de 30, talvez nem o governo nem a sociedade em si tivessem a consciência desse subdesenvolvimento brasileiro que afetava, principalmente, as classes mais baixas. É nesse contexto que os intelectuais começaram a "sofrer o dilema: denunciar as misérias das condições de vida de grande parte da população e discutir a relação produto-capital" (OLIVEIRA, 2003, p. 32). Dessa forma, a Literatura passou a focar em aspectos que evidenciavam o atraso material e valorizavam o regionalismo, o que garantiu uma visão da pré-consciência do subdesenvolvimento, a qual não foi positiva, pois as mazelas brasileiras, principalmente as voltadas para o campo, afloraram.

Com essa sequência, os intelectuais ficaram com a responsabilidade de detectar os problemas e atuar sobre eles. Contudo, desenvolver a intelectualidade no período Vargas, principalmente durante o Estado Novo, foi laborioso, visto que a maioria deles lutou contra a política de Getúlio e o antifascismo.

Foi nesse contexto que Graciliano Ramos se destacou como escritor e intelectual, disposto a identificar e mostrar ao mundo as misérias sociais.

Sempre engajado e resistente, Graciliano desenvolveu a intelectualidade em um período ímprobo, quase miserável de questões humanitárias, o que tornou ainda mais difícil exercer o procedimento de homem pensante e disposto a transpor para o papel meios de discutir os problemas sociais.

Na opinião de Moraes (2012, p. 74), Graciliano é visto como um exemplo "no sentido de comportar, em um único percurso existencial, um conjunto de significativas e não menos turbulentas experiências, como cidadão, intelectual e ativista". Resumindo, assim, um homem que abandonou os possíveis meios de se esquivar da real visão dos anos 1930 e dar consciência a uma legião que estava vendada para as questões humanas e igualitárias. 
A vulnerabilidade da sociedade civil fez com que Graciliano Ramos se envolvesse e encarasse o sistema autoritário governamental de forma real e combativa. É evidente que alguns intelectuais sofreram de modo silencioso, mas Graciliano suportou a opressão da época. E desenvolver a intelectualidade durante o Estado Novo tornava-se algo árduo, visto que o índice de analfabetismo era grande e o regime era penoso.

Já que o índice de analfabetismo estava em alta e muitos escritores estavam sofrendo com o regime tirano, viver de Literatura era praticamente impossível. Assim, os intelectuais associaram-se à política, pois, talvez, fosse o melhor meio de desenvolver a intelectualidade.

Porem, Graciliano, ainda não filiado como comunista (fato que ocorreu somente em 1945), destacava seu desprezo pelo governo de Getúlio e por seu estilo fascista, como afirma Dênis de Moraes, ao dizer que "Graciliano odiava o Estado Novo a ponto de cuspir no chão toda vez que alguém se referia à ditadura na roda literária da livraria José Olympio" (MORAES, 2012, p. 81).

Assim, a intelectualidade de Graciliano durante o Estado Novo baseouse em estudar as ações para que fossem válidas, já que a zona de conflito era sinuosa. E a divulgação das ideias libertadoras e igualitárias deveria ser estudada junto com o pensamento livre do escritor.

Dessa forma, Memórias do Cárcere foi uma espécie de desabafo e de exposição das ideias engajadas. Mesmo publicado anos após a prisão, o livro trouxe a voz que tanto os intelectuais buscaram durante o Estado Novo e, até mesmo, um pouco antes da Ditadura.

\section{2 - NARRADOR E PERSOANGENS}

Durante a década de 30, Graciliano Ramos publicou quatro grandes romances: Caetés, São Bernardo, Angústia e Vidas Secas. Os narradores dos três primeiros são personagens: João Valério, Paulo Honório e Luís da Silva. 
Já em Vidas Secas, símbolo da pré-consciência do subdesenvolvimento, o narrador configura-se em $3^{\text {a }}$ pessoa onisciente dando voz aos excluídos e destacando o drama da falta, já que, para a família de retirantes, tudo simbolizava a ausência: ausência de um lar, de um futuro, de uma linguagem. Dessa forma, em 1938, Graciliano deixou evidente que, para os sertanejos, o mundo era pequeno demais e não havia lugar para eles, já que o sistema não elaborava um meio de enquadrar essa parte da sociedade em uma vida digna e respeitável. A única salvação era continuar com a trajetória cíclica da família, baseada numa vida nômade e mantendo a linguagem seca como a vida.

Já nos outros romances citados anteriormente, a preferência pelo narrador-personagem faz com que Graciliano dê voz a vários setores da sociedade, como por exemplo o pequeno-burguês com João Valério, o latifundiário representado por Paulo Honório, e a classe média, realçada por Luís da Silva. É relevante lembrar que os narradores-personagens de Graciliano "são todos escritores - ou têm pretensão de sê-lo, e estão às voltas com o fazer literário como atividade árdua, dolorosa, reflexiva e insuficiente para suas necessidades de expressão" (BRUNACCl, 2008, p. 16).

Dessa forma, a Literatura proposta por Ramos procurou cruzar a arte com a sociedade, levando o leitor a enxergar e a conhecer o lado que, geralmente, estava oculto dentro do contexto social; fazendo com que laços de estreita relação fossem criados entre a sociedade e suas contradições. "Falar de carências e falta de horizontes foi para ele uma maneira de sensibilizar o leitor". (ABDALA, 2012, p. 170).

Então, a escolha do narrador ideal está diretamente ligada ao processo criador, para que a literatura se apresente na obra de modo real e engajado.

Para Alfredo Bosi, o realismo crítico de Graciliano Ramos baseia-se no distanciamento que o autor consegue implicar à obra, colocando todo 0 conhecimento dos entraves e também das restrições que a vida rústica nordestina dispunha nas mãos do narrador (BOSI, 2003, p. 33).

Em Memórias do Cárcere, Graciliano Ramos, apesar de não se sentir bem usando a primeira pessoa e tendo ele próprio como narrador, não 
considerou a possibilidade de criar um narrador fictício ou até mesmo escolher outro personagem para que assumisse a voz da narrativa. Relembrar as memórias dos dez meses em que esteve emparedado e contá-las de uma maneira bastante subjetiva, com acertos e enganos, precisava ser feita pela voz que, mesma presa, não se calou diante da reclusão.

Desgosta-me usar a primeira pessoa. Se se tratasse de ficção bem: fala um sujeito mais ou menos imaginário; fora daí é desagradável adotar o pronomezinho irritante, embora se façam malabarismos por evitá-lo. Desculpo-me alegando que ele me facilita a narração.. (RAMOS, 2008, p. 15)

Há também narradores, e um já nos deu há tempo, excelente reportagem, dessas em que é preciso dizer tudo com rapidez. Em relação a eles, acho-me por acaso em situação vantajosa. [...] Posso andar para a direita e para a esquerda como um vagabundo, determe em longas paradas, saltar passagens desprovidas de interesse, passear, correr, voltar a lugares conhecidos. Omitirei acontecimentos essenciais ou mencioná-los-ei de relance, como se os enxergasse pelos vidros pequenos de um binóculo; ampliarei insignificâncias, repeti-las-ei até cansar, se isto me parecer conveniente. (RAMOS, 2008, p. 14)

"Nesta reconstituição de fatos velhos, neste esmiuçamento, exponho o que notei, o que julgo ter notado" (RAMOS, 2008, p. 15). Graciliano, como narrador-personagem de sua própria história, conseguiu manipular melhor os acontecimentos, os quais foram dispostos de uma maneira muito verossímil, a qual realmente aproxima o leitor da cena apresentada. Porém, ao mesmo tempo em que Graciliano faz minúcias dos fatos, ele também se mostra confuso em algumas situações, misturando realidade com delírio, um dos efeitos da cadeia.

Por isso que, apesar de Memórias do Cárcere ser uma história verídica, o modo como Graciliano narrador a administra é ficcional (MARQUEZINI, 2006, 
p. 134), já que, em muitas partes, a memória falhou e a suposição de que estava delirando dentro da prisão também não contribuiu para que todas as afirmações fossem contadas de forma real.

\footnotetext{
Também me afligiu a idéia de jogar no papel criaturas vivas, sem disfarces, com os nomes que tem no registro civil. Repugnava-me deformá-las, dar-lhes pseudônimo, fazer do livro uma espécie de romance, mas teria eu o direito de utilizá-las em história presumivelmente verdadeira? (RAMOS, 2008, p. 11)
}

Apesar dos entraves físicos e psicológicos que Graciliano sofreu em algumas situações dentro do cárcere, a narração mostra-se de uma maneira muito apropriada, a qual Ramos expõe muito bem as particularidades tanto da cena, quanto de alguns personagens. Esse detalhamento deixa a narrativa morosa, mas é essencial para que a mesma aproxime-se mais da realidade.

No que se observa de Graciliano Ramos como narrador é que esse, constantemente, se autoanalisa, buscando por meio dos defeitos dos outros, revelar os seus. Ao mesmo tempo em que valores que já o acompanhavam são repensados, modulando-os por meios mais flexíveis de se enxergar a realidade.

Essa autoanalise possibilitou, também, demonstrar suas fragilidades e, ao mesmo tempo, rever seus conceitos em relação à convivência, por exemplo. Por isso, Ramos afirma que, a partir da prisão, aprendeu a compreender primeiro do que julgar (RAMOS, 2008, p. 13).

De fato, o autor como voz narrativa passa a se conhecer na medida em que as dificuldades vão surgindo; e o cárcere era um ambiente propício para que isso acontecesse. Durante a exposição dos fatos, Ramos exibe características e sentimentos que, talvez, nem ele mesmo sabia que possuía; assim, o processo de autoconhecimento é marcado durante toda a narrativa, porém, em algumas situações específicas, esse processo fica mais acentuado, pois revela uma reflexão mais profunda do narrador ou até mesmo a mudança de seu comportamento. 
Um exemplo desse processo de autoconhecimento, talvez até um caso pouco relevante dentro da obra, mas que, com certeza, permitiu que Graciliano se obervasse, colocando-o do lado oposto da situação, foi seu encontro casual com Miguel Batista.

Logo após receber seu mandato de prisão, partindo do Batalhão dos Caçadores com destino a Recife, Graciliano encontrou na estação do trem da Great Western um velho conhecido: Miguel Batista. Na época, Batista era juiz de direito do interior, mas já havia correspondido com Graciliano, quando esse trabalhava na prefeitura de Palmeira dos Índios. No encontro, Batista desejou felicidades a Ramos, dizendo-Ihe que sua prisão era injusta e equivocada e que voltaria em breve.

Graciliano, como bom ranzinza que era, não concordou com Miguel, afirmando a ele que não voltaria. Ramos ficou perplexo com a atitude do conhecido, a cordialidade fora de hora mexeu com o jeito frio do narrador de encarar a situação. E, a partir disso, Graciliano colocou-se no lugar de Batista e chegou à conclusão de que se os papéis estivessem invertidos, ele, Ramos, não seria tão amável assim:

\footnotetext{
$\mathrm{Na}$ ausência de Batista, indaguei-me. Se os nossos papéis estivessem trocados, haveria eu procedido como ele, acharia a maneira conveniente de expressar um voto generoso? Talvez não. Acanhar-me-ia desatento. Essas descobertas de caracteres estranhos me levam a comparações muito penosas: analiso-me e sofro. (RAMOS, 2008, p. 38)
}

A descoberta dos primeiros "caracteres estranhos" os quais se revelaram, por vezes, a partir de acontecimentos pequenos, foram extremamente importantes para a construção e transformação desse narradorpersonagem que vai ganhando proporções que o levam ao processo de autoanálise na medida em que a narrativa se desenvolve. Por isso, o leitor consegue enxergar que, ao final da narrativa - período em que Ramos permanece na Casa de Correção - é bem nítida a mudança que ele revela em relação a alguns conceitos. 
Outro exemplo disso é a questão da homossexualidade dentro do cárcere, a qual Ramos presenciou desde o pavilhão dos primários até a Casa de Correção. Graciliano sentia nojo do ato homossexual entre os homens que habitavam o sistema carcerário, e, no início, foi difícil conviver, mesmo que não tão próximo assim, com o que denominava de horror. Porém, ao final da narrativa, Ramos já mostra empatia em relação à homossexualidade vivida por alguns presidiários.

Walter Pompeu cortou-me o almoço e o jantar. Sentava-se à minha direita, na primeira mesa. E, percebendo o horror que me inspira o homossexualismo, iniciou um jogo desonesto no refeitório. [...] Necessário justificá-los. Mas isso ficava em explicação e afastava-me dos corpos imundos com excessivo nojo. Esforçava-me por vencer a repugnância. Poderia dizer onde estava o normal, o anormal? [...] Afinal, o procedimento daqueles indivíduos explicava-se pela necessidade, mas seria preciso imaginar que também os atos do garoto, julgados porcos sem nenhuma explicação deveriam constituir uma necessidade para ele. (RAMOS, 2008, p. 581 - 582)

A flexibilidade que o narrador adquire durante a narrativa é moldada diante dos acontecimentos e das ausências que ele sofreu no decorrer do período carcerário. Essa transformação leva-nos a perceber que, a partir do momento em que o indivíduo vivencia a necessidade do outro, fica mais fácil entender e compreendê-la. "Para haver alteridade é preciso que alguém (individual e lou coletivamente) se constitua como outro" (BRUNACCI, 2008, p. 12).

Entretanto, apesar de Graciliano apresentar essa maleabilidade em relação a alguns de seus valores, outros permaneceram intocáveis para ele, e a forma como ele dispõe de sinceridade em relação a isso deixa a narrativa mais próxima dos questionamentos sociais da época, como, por exemplo, o modo como enxergava o exército. 
O fato de ser irônico e de essa característica, por algumas vezes na obra, chegar ao humor não demonstra que em relação ao exército e seus simpatizantes Graciliano apenas queria dar uma "alfinetada", mas, de fato, Ramos queria mostrar sua antipatia por esse sistema, o qual achava desnecessário e equivocado. "Habituara-me cedo a considerar o exército uma inutilidade. Pior: uma organização maléfica" (RAMOS, 2008, p. 44).

Quando Graciliano chegou a Recife, no Forte das Cinco Pontas, deparou-se com o sistema militar chefiando seus passos e suas atitudes e foi obrigado a conviver com isso. Contudo, ao encontrar o general Newton Cavalcanti - cujo o nome não é citado na narrativa, talvez de forma proposital , Ramos não escondeu sua ironia nem mesmo seu desinteresse pelas forças militares.

Houve somente um encontro entre os dois, porém, foi o suficiente para que essa antipatia se reafirmasse. Newton Cavalcanti foi um dos responsáveis pela prisão de Ramos em 1936, "um dos próceres da linha-dura no Exército e com quem o líder integralista Plínio Salgado se orgulhava de ter" (MORAES, 2012, p. 114). Na verdade, Cavalcanti ordenou a prisão de todos os indivíduos que não simpatizavam com as ideias do governo de Getúlio Vargas.

Pela manhã [...] avistamos o comandante em companhia de um homem alto, magro e sério. Enviamos-lhe cumprimentos, e ele nos deteve, nos apresentou:

-- General, estes senhores...

Finda a apresentação, o homem pregou-me um olho irritado:

-- Comunista, hem?

Atrapalhei-me e respondi:

-- Não.

-- Não? Comunista confesso.

-- De forma nenhuma. Não confessei nada.

Espiou-me um instante, carrancudo, manifestou-se: 
-- Eu queria que o governo me desse permissão para mandar fuzilá-lo.

-- Oh! General! Murmurei. Pois não estou preso? (RAMOS, 2008, p. 74)

Por sorte, o general não deu importância aos dizeres de Graciliano e encerrou o encontro.

A imensa sinceridade com que tratou dos assuntos que não the agradavam torna a narrativa impactante, com caracteres de uma literatura em choque com as desavenças políticas e sociais da época.

Essas características também se manifestam em outras obras de Graciliano, acoplando-se com a linguagem seca e precisa, com tendências para discussões que declaravam o antagonismo do Brasil na década de 30, dividido entre uma nação pré-disposta à modernização, principalmente nas metrópoles, e o Brasil atrasado, afundado nas carências.

Não é mera coincidência que os livros didáticos trabalhados nas escolas com ensino médio, ao retratarem a segunda fase do modernismo brasileiro, classificam a obra de Graciliano como Neorrealista, por apresentar características que os romances realistas/naturalistas do final do século XIX também já dispunham, porém, agora voltados para a realidade política e social, dando enfoque aos menos privilegiados.

Ainda sobre o modo de como Graciliano expôs o exército no contexto de Memórias do Cárcere, apesar de sua antipatia por esse sistema, Graciliano conseguiu separar atitudes boas e sinceras de quem estava ao lado dos militares, como é o caso de Capitão Lobo.

Durante sua estadia no Forte das Cinco Pontas, em Recife, Graciliano manteve contato com José de Figueiredo Lobo, em Memórias do Cárcere citado apenas como Capitão Lobo. Lobo era um dos responsáveis pelos presos políticos dentro do Forte e, a maneira como Graciliano o descreve, de início, aparenta ser mais um integrante seco e bem ríspido do exército, treinado para cumprir ordens. 
Levantava-me quando entrou um moço grave, de olhos vivos, ligeiramente estrábicos, fumando por uma longa piteira.

-- Capitão Lobo.

Passeando da mesa para a janela e da janela para a mesa, deu-nos esclarecimento:

-- Os senhores ficam alojados aqui.

[...] Esteve meia hora a conversar com volubilidade, afirmativo, às vezes sublinhando a frase com movimentos enérgicos. Não ria, não sorria: as ideias deviam parecer-lhe coisas terrivelmente sérias. Parava para escutar, aprovando ou desaprovando com a cabeça, retomava depois o discurso e o passeio ambos em linha reta. (RAMOS, 2008, p. 54)

Contudo, no próximo encontro que tiveram, Capitão Lobo manifestou vontade de se aproximar de Graciliano, dizendo a ele que respeitava suas ideias, mas que não concordava com elas (RAMOS, 2008, p. 59). Essa exposição de Lobo inquietou Graciliano, pois ele não entendeu como um oficial do exército atrevia-se a se comunicar de tal maneira com um preso político. E, para não se complicar mais, Graciliano calou-se diante das afirmações de Lobo. Porém, Graciliano não sabia que Capitão Lobo simpatizava-se com sua literatura, pois já havia apreciado Caetés e São Bernardo, daí sua admiração por Ramos que se tornou secreta naquele contexto (MORAES, 2012, p. 117).

Tal admiração levou Lobo a oferecer regalias durante os dias em que Graciliano esteve preso, como por exemplo, mandou buscar roupas limpas em sua casa. Dessa forma, Ramos começou a perceber que, apesar de ser um oficial do exército, Lobo era um homem bom, "a sinceridade transparecia no rosto claro" (RAMOS, 2008, p. 59). Assim, a construção de Capitão Lobo como personagem transpassa ao leitor a figura de um homem amável, que não compactuava, por inteiro, com o regime ríspido e inflexível do exército e, então, Graciliano começou a simpatizar-se por ele. "-- Não concordo com as suas ideias, mas respeito-as. [...] Era o que me levava a admirar Capitão Lobo. Isso e a suspeita de me achar diante de uma criatura singular" (RAMOS, 2008, p.73). 
Dênis de Moraes, em 2012, ao publicar uma biografia de Graciliano, conseguiu algumas considerações que Capitão Lobo fez em 1970: "como bom nordestino, ele era muito desconfiado, julgava que meus diálogos eram para espioná-lo. Estava com horror à farda" (MORAES, 2012, p. 118).

E Graciliano, de início, estava enganado. Esse engano é remodulado pelo narrador, o qual páginas seguintes mostra sua admiração por Lobo, reafirmando uma impressão favorável do oficial. Isso se confirma quando Graciliano estava para deixar o Forte em Recife, com destino ao Rio de Janeiro. Capitão Lobo ofereceu dinheiro a Ramos, para que ele não viajasse com pouco ou sem nada no bolso. Lobo afirmou a Ramos que aquela proposta não era um favor, mas sim um empréstimo.

Esse "disparate" entonteceu Ramos, proposta absurda e fora de hora. Graciliano gastou páginas tentando entender o porquê daquele acontecimento, um oficial desconhecido oferecendo dinheiro a um preso, sem nenhuma recompensa imediata. Graciliano tentou compreender possíveis motivos para que Capitão Lobo fizesse isso, um dos mais prováveis era para que Ramos se comprometesse ainda mais com as forças políticas, e disso inúmeras indagações surgiram.

Não supunha os homens bons nem maus: julgava-os sofríveis, pouco mais ou menos razoáveis, naturalmente escravos dos seus interesses. [...] Era possível então alguém proceder de tal maneira? Por quê? [...] Sem dúvida um homem que resolvia prejudicar-se em benefício de um estranho não estava em seu juízo perfeito. (RAMOS, 2008, p. 90)

Porém, o narrador, por meio do delineamento da figura de Lobo no contexto, constata que aquele oficial era um ser ímpar dentro do sistema, capaz de demonstrar gestos generosos e desprovidos de interesses. Graciliano, obviamente, recusou o empréstimo, foi uma recusa "chocha", desprovida de palavras, embaralhada nas afirmações, mas Ramos, no momento, não conseguiu enxergar as boas intenções do oficial. 
Mesmo assim, a figura de Capitão Lobo encerra-se pelo narrador como alguém especial, transparente e com feições bondosas, contrária às ações que o exército impunha a seus homens.

A partir disso, Graciliano, mais uma vez, reanalisou seus pensamentos, e afirmou que "a exceção nos atrapalha, temos de reformar julgamentos" (RAMOS, 2008, p. 93). Essa análise constante do narrador permitiu que a observação de seus comportamentos e valores fosse repensada, mesmo que de maneira crítica e atordoada, já que Ramos sofria com essas análises. E assim, viu na prisão possibilidade de descobrir novos conceitos em relação ao ser humano.

\footnotetext{
Realmente a desgraça nos ensina muito: sem ela, eu nunca continuaria a julgar a humanidade incapaz de verdadeira nobreza. Eu passara a vida a considerar todos os bichos egoístas - e ali me surgia uma sensibilidade curiosa, diferente das outras, pelo menos uma nova aplicação do egoísmo, vista na fábula, mas nunca percebida na realidade. Para descobri-la não era muito aguentar algumas semanas na cadeia. Seriam apenas algumas semanas? (RAMOS, 2008, p. 94)
}

Para que essa hipótese de autoanalise do narrador e transformação comportamental durante o desenvolvimento da narrativa se confirme, a viagem de Recife ao Rio de Janeiro, dentro do porão do navio Manaus se faz muito condizente.

Durante os dias em que enfrentou o confinamento dentro da embarcação, Graciliano caracteriza-se por uma mistura de sentimentos confusos, alguns chegaram a distorcer a sanidade do narrador, alternando entre a ideia de realidade absurda e possíveis alucinações.

Graciliano Ramos manipulou esses sentimentos com muita sabedoria, ministrando de forma sensata situações em que, talvez, a raiva e o medo pudessem o fazer agir de maneira impensável, provocando consequências desagradáveis e irreversíveis. 
Uma qualidade que o narrador apresenta em toda a narrativa, desde quando recebeu o mandato de prisão em sua casa, até seus últimos momentos dentro do cárcere, foi a flexibilidade em se adaptar, ou pelo menos tentar, em cada ambiente pelo qual passou nos dez meses em que ficou recluso. No porão do navio Manaus, essa adaptação esteve mais relevante, pois as condições básicas de sobrevivência eram precárias e, como afirma Ramos, "estávamos ali mortos, em decomposição" (RAMOS, 2008, p. 117).

Um dos primeiros sentimentos que o narrador vivenciou dentro do navio foi a raiva, muito bem pautada por momentos em que a vontade de agir de forma súbita era maior, contudo não conveniente.

No primeiro contato com a embarcação, um negro no degrau da escadaria que o levava até o porão, encostou uma pistola nas costas de Ramos, simbolizando a força que aqueles homens que estavam ali mantinham sobre os presos. Graciliano considerou a atitude "ridícula" e "vergonhosa", desnecessária para o momento.

A maneira como o narrador se mostra em situações como esta, talvez, para o leitor, seja inesperada, já que por ser um homem genioso, como era considerado, Graciliano soube aquietar-se em horas desfavoráveis, acentuando uma serenidade imprevista. Graciliano afirmou que em situações de "raiva fria e impotente, [...] temos de morder os beiços e baixar a cabeça, engolir a afronta" (RAMOS, 2008, p. 103).

A condição física de Ramos foi outra característica que serviu para pautar o narrador. A desonra moral que atingia Ramos naquele momento já não se manifestava de forma perturbadora e inquietante, pois ele sabia que ela não o "salvaria" daquela condição aterrorizante na qual se encontrava. "Não era a degradação moral que me oprimia" (RAMOS, 2008, p. 105).

Graciliano, de fato, preocupou-se com sua forma física, a qual estava prejudicada por alguns problemas de saúde, como, por exemplo, as dores na perna que havia sido operada anos antes. Além da falta de apetite, expandida ainda mais pela comida horrível que a embarcação oferecia aos presos, o consumo excessivo de cigarro, o qual era visto como uma espécie de fuga da 
realidade incoerente, - "se esgotássemos a reserva mesquinha, estaríamos desarmados e a vida se tornaria insuportável" (RAMOS, 2008, p. 164) também contribuiu para que Graciliano imergisse num desânimo profundo, enxergando a morte como solução dos momentos tensos que viveu ali.

O porão do navio Manaus constituía-se como um lugar insalubre, coberto por uma névoa nojenta, misturando suor com urina e outros dejetos que cobriam o chão. Além da pouca luz que tentava iluminar os homens que espremiam-se entre si e suas bagagens, o calor também aumentava a degradação do lugar. O narrador caracterizou os homens que ali estavam como bichos encaixotados, revelando uma visão grosseira e realista da degradação humana.

A linguagem que Graciliano Ramos usa para descrever o ambiente nocivo é bem indelicada, com características naturalistas, ressaltando aspectos negativos, transparecendo o nojo que aquele lugar causava. Além disso, a caracterização do ambiente lotado por homens desconhecidos e submetidos àquela situação revela aspectos que chegam a ser irônicos, beirando à agressão e expondo a animalização daqueles indivíduos.

\begin{abstract}
Tentando reduzir o calor, afastar o cheiro horrível, mistura de suor e amoníaco [...]. No zunzum de feira nenhuma frase perceptível: os meus pés machucavam coisas moles, davamme a impressão de pisar em lesmas, o terrível fedor sufocavame, a quentura de fornalha punha-me brasas na pele, e a certeza de encontrar-me cercado de imundices levava-me a proteger a valise, resguardá-la debaixo do braço. Aguentar-meia em semelhante lugar? Conseguiria resistir? (RAMOS, 2008, p. $104-105)$
\end{abstract}

Apesar do pouco tempo em que Ramos passou dentro do porão do navio Manaus, os sofrimentos físicos e psicológicos foram tão impactantes que o tempo parecia não correr, metaforizando uma eternidade. $\mathrm{Na}$ difícil adaptação, o narrador consegue expor-se de maneira muito tranquila, lutando contra sua má disposição física e contra o cenário aterrorizante. 
Graciliano mostra que as pessoas que o acompanhavam ali foram fundamentais para que as horas horríveis dentro da embarcação fossem amenizadas.

No porão do Manaus, tinha-me visto na companhia de pessoas aviltadas, e o ambiente físico me atormentara a princípio. No entanto, conseguira habituar-me. Era possível escapar dali refugiando-me no camarote do padeiro, na rede a balançar embaixo da escotilha. E a convivência de Lauro Lago, Macedo, Mário Paiva, Benon, João Anastácio, Manuel Leal de nenhum modo me desagradava. Ligeiras incompreensões anulavam-se. (RAMOS, 2008, p. 313)

As "criaturas" que estiveram presentes nessa viagem foram essenciais para que o narrador pudesse dar voz à humilhação que muitas pessoas passaram durante o governo autoritário de Getúlio. Mesmo que de maneiras diferentes, cada indivíduo foi captado por Ramos de modo muito particular, enfatizando algumas características miúdas, mas que Graciliano observou muito bem.

O meu desejo era retratar os circunstantes, mas, além dos nomes, escassamente haverei gravado fragmentos deles: os olhos azuis de José Macedo, a contração facial de Lauro Lago, a queimadura horrível de Gastão, as duas cicatrizes de Epifânio Guilhermino, o peito cabeludo e o rosário do beato José Inácio, a calva de Mário Paiva, os braços magros de Carlos Van der Linden, o rosto negro de Maria Joana iluminado por um sorriso muito branco. (RAMOS, 2008, p. 133)

A boa observação de Ramos e a busca de pelo menos um detalhe de cada indivíduo que o acompanhou durante o período carcerário são características que o narrador expande por toda a narrativa. Mas, alguns personagens são ressaltados por Ramos, àqueles que, de alguma forma, manifestaram-se para que a vida naquele momento fosse mais leve, apesar do contexto.

É o caso de Mário Paiva, retratado por Ramos como um talento para a comicidade. A flauta do Lobato, cantiga cantada e recantada por esse 
personagem, superou os momentos de ócio e desânimo que atingiam aquelas pessoas. Graciliano descreve Paiva de uma maneira bem serena que, mesmo perturbando a todos com a repetição excessiva da cantiga, não media esforços para trazer um pouco de alegria e sorrisos no ambiente. O sorriso constante no rosto espalhava esperança e contagiava de alguma maneira os integrantes daquele porão.

Ramos deixa claro que esse personagem, em seus minutos de silêncio, fazia falta em meio ao caos e, assim, quando o observava calado, solicitava seus trabalhos novamente:

A habilidade cênica de Mário Paiva expunha-nos com frequência a flauta do Lobato. A tagarelice desenxabida amolava-me. Contudo habituei-me a ela: estranhava os rápidos silêncios do homem e buscava importunar-me novamente:

--- De quem é a flauta, Mário Paiva?

E a resposta vinha pronta, mal cantarolada:

A flauta era de Lobato.

Minha avó sempre dizia:

--- Toca flauta, seu...

Lobato tinha uma flauta.

A flauta era de Lobato. (RAMOS, 2008, p. 140)

Após isso, Graciliano descreve Mário Paiva, que o acompanhou no Pavilhão dos Primários, mas lá não exerceu o mesmo papel pelo qual tanto foi admirado no navio. Mário já esboçava um ar cansado, aparentemente doente e a alegria desse personagem foi deixada para trás - primeiras consequências que a cadeia Ihe proporcionava. "Mário Paiva chegou silencioso, triste, com ar doentio; nunca mais tornamos a ouvir a flauta de seu Lobato" (RAMOS, 2008, p. 215). 
O navio Manaus transportou os presos até o Rio de Janeiro, atracando na Baía de Guanabara no dia 14 de março de 1936. Após uma jornada entre um presídio e outro, Ramos e seus companheiros foram acomodados na Casa de Detenção que ficava na rua Frei Caneca. Depois de preencher uma ficha, Graciliano foi mandado para o Pavilhão dos Primários.

A preocupação que Graciliano demonstra em relação ao detalhamento de alguns dos indivíduos que encontrou e também do ambiente, durante sua estadia no Pavilhão dos Primários, é importante para que a narrativa se desenvolva de forma realista, como falado anteriormente.

Durante os quatro meses em que Graciliano passou dentro do Pavilhão, mais de cinquenta nomes foram anotados, observados e levados em consideração no desenrolar da narrativa. O narrador mostra-se muito específico com o detalhamento dos personagens, esboçando minúcias físicas e psicológicas. Graciliano mostra-se como um excelente observador, e dessa observação consegue extrair de cada um as misérias e pedaços de esperança que ainda restavam.

Para que a definição dos personagens fosse modulada, Graciliano também descreve muito bem as características físicas da cadeia, detalhes de cada cubículo em que esteve. Isso se faz fundamental, pois boa parte dos comportamentos de seus companheiros de cela e até mesmo os de Graciliano, estão relacionados, de alguma forma, com a estrutura física e também com o funcionamento da prisão.

Dênis de Moraes caracteriza essa parte da narrativa como "um estranho no ninho", mas, apesar dessa classificação, o Pavilhão dos Primários foi um dos lugares que, durante todo o período carcerário, Graciliano melhor se adaptou. Fez amizades e alguns laços permaneceram após a saída da prisão, aprendeu a conviver com pessoas completamente diferentes, as quais, algumas, soube observar de maneira mais íntima. As necessidades que passou ali foram fundamentais para que Graciliano conseguisse compreender melhor a estreita relação entre os homens e suas limitações. 
O Pavilhão dos Primários funcionava bem de acordo com as descrições que o narrador fez. "Em forma de $U$, era uma construção ampla, de dois andares, com cinquenta cubículos, onde se comprimiam cerca de duzentos presos envolvidos na insurreição, a maioria jovens militares" (MORAES, 2012, p. 122).

Apesar da precariedade das condições carcerárias, o Pavilhão dos Primários oferecia um pouco mais de conforto aos presos, comparado ao porão do navio Manaus. Ramos afirma que no Manaus as pessoas eram bichos, e quando chegavam ao pavilhão viravam gente (RAMOS, 2008, p. 290).

A cadeia era vista como um organismo político, cada cubículo possuía seus "moradores" que se organizavam da maneira que fosse mais conveniente. Além disso, algumas regalias foram conquistadas dentro do cárcere: os presos podiam circular até às dezenove horas pela Praça Vermelha. Também contavam com a ajuda do Coletivo, grupo de presos, o qual fora eleito de forma democrática e cabia a ele que fizesse a ligação entre o mundo exterior e os presidiários, já que o diretor do pavilhão raramente aparecia.

O narrador ressalta a dificuldade que teve, no início, de aceitar as cordialidades que aquele sistema organizado oferecia a ele. Ramos não esperava chegar à prisão e vivenciar um ambiente em que as pessoas contribuíssem de maneira favorável para que tudo ali mantivesse um andamento estabilizado.

\footnotetext{
Percebi entre os meus companheiros uma esquisita amabilidade: antes de pedir, ofereciam. [...] os meus escrúpulos me levariam a recusar assistência, ainda que me achasse em penúria. [...] Trava-se então de saber se me era possível contribuir para o Coletivo. Mas que vinha a ser aquilo? Um organismo a funcionar, com excelentes resultados, em prisão política. A oferta e o pedido me revelavam de pronto um dos seus fins: estabelecer o equilíbrio (RAMOS, 2008, p. 198).
}

Ramos também notou que os presos organizavam atividades para que os dias não ficassem ociosos. Nos cubículos, havia uma espécie de biblioteca, 
oferecida pelos próprios presidiários, com obras que eram trazidas pelos familiares. Existiam também cursos de línguas, Marxismo, Filosofia, os quais também eram ministrados pelos presos, já que a maioria deles era insigne.

O jogo de xadrez acrescentava-se às atividades carcerárias, o qual foi introduzido e improvisado por Vandemar Birinyi - húngaro, que se perdeu na viagem ao Brasil e fora preso por não saber explicar as razões pelas quais o trouxeram ao país. Ramos afirmava que Birinyi vivia calado e isolava-se demais, por isso o jogo de xadrez foi uma tentativa para que ele não caísse em profundo desânimo dentro da cadeia.

Certo dia traçou numa folha de almaço um tabuleiro de xadrez, fabricou peões, torres, cavalos, bispos, reis e rainhas com miolo de pão, coloriu de azul as peças e as casas pretas. Desde então aquele divertimento nos encheu as horas, venceu as lições, as cantigas da rádio libertadora. (RAMOS, 2008, p. 223)

Graciliano adaptou-se aos poucos nesse novo cenário e, apesar de possuir condições um pouco melhores, o modo como algumas coisas funcionavam lá dentro causavam choque e estranhamento. Ramos salienta bem a comida que, assim como no porão do navio Manaus, continuava intragável.

Aquele dia a comida veio muito ruim, de aspecto mais desagradável que o ordinário. No caixão, ao pé da grade, empilhavam-se os pratos - e o alimento se comprimia formando uma pasta onde se misturavam carne, peixe, arroz e batatas esmagadas. (RAMOS, 2008, p. 262)

Nesse mundo de novas convenções e costumes, Ramos adaptou-se e soube transformar o que era pra ser algo inaceitável em flexibilidade. Aprendeu a se equilibrar em cima dos tamancos, acomodou-se nos colchões que, apesar de muito duros e lotados de percevejos, serviu de apoio para o corpo cansado. 
Além disso, a Rádio Libertadora - criada pelos presos - também encantava Ramos e o deixava fascinado com a criatividade daqueles homens. Ramos a descreveu assim: "Não era apenas um divertimento arranjado com o fim de matar tempo e elevar o ânimo dos presos: vieram notícias de jornais, comentários, acerbas críticas ao governo, trechos de livros, o Hino do Brasileiro Pobre, algumas canções bastante patrióticas, sambas" (RAMOS, 2008, p. 199).

Graciliano tentava participar das atividades carcerárias, talvez de uma forma mais reservada, media as palavras e não se colocava como foco das atenções, pois seu objetivo ali não era fazer revolução com suas próprias mãos, mas sim observar e tentar compreender um pouco de cada indivíduo que o cercava.

Contenho-me ao falar a desconhecidos, acho-os inacessíveis, distantes; qualquer opinião diversa da minha choca-me em excesso; vejo nisso barreiras intransponíveis - e revelo-me suspeitoso e hostil. Devo ser desagradável, afasto as relações. (MORAES, 2012, p. 123)

A necessidade de escrever o perturbava, sentia vergonha por estar parado, por isso as folhas de papel e o lápis o acompanhavam. Logo que chegou ao pavilhão, sua observação sobre as coisas e as pessoas foi certeira, sabia que daquelas anotações poderia sair uma boa história. Era fundamental que começasse a anotar os nomes de seus companheiros carcerários e observá-los.

Veio-me a idéia de pedir-lhe esclarecimentos a respeito dos habitantes daquela prisão. Desmanchei uma carteira de cigarros, tirei de um dos lados o cartão que tenho aqui sobre a mesa, tomei o lápis e escrevi alguns nomes: Romariz, Adolfo, Renato, Sérgio.

-- Sérgio de quê? Perguntei. Qual é seu sobrenome? (RAMOS, 2008, p. 191)

A quantidade de presos e também a insuficiência de lugares para que todos pudessem se acomodar em determinada prisão faziam com que a permanência de cada um fosse instável, não sabiam por quanto tempo iam 
continuar ali, nem para onde seriam transportados. Essa oscilação comprometia as anotações de Ramos, pois não conseguia manter um registro fixo das pessoas, para que ele pudesse observá-las de maneira mais profunda. "Essa mobilidade nos causava receio constante. Não nos permitiam conhecernos bem; relações imprecisas, camaradagens mal esboçadas, estavam sempre a desfazer-se" (RAMOS, 2008, p. 230).

Apesar da inconstância, alguns nomes sobressaem-se dentro da narrativa, e o leitor consegue perceber que Graciliano tentou, pelo menos, esboçar algum atributo dos homens e das mulheres que, de alguma forma, conviveram com ele durante esse período. Ainda assim, alguns personagens foram mais significativos para Ramos, alguns por maior aproximação, outros por características singulares.

Um exemplo disso é a figura de Rodolfo Ghioldi, um dos primeiros a chamar a atenção de Graciliano dentro do Pavilhão dos Primários, não somente por sua ótima disposição com as palavras, mas por ser diferente. "O rapaz simpático e franzino, de cuecas e tamancos, era Rodolfo Ghioldi” (RAMOS, 2008, p. 192).

Ghioldi era argentino e secretário do Partido Comunista de lá. A facilidade com que ele lidava com as palavras encantou Graciliano: "[...] tomeime de verdadeiro espanto: nunca ouvira ninguém expressar-se com tanta facilidade" (RAMOS, 2008, p. 195). Como sábio orador das palavras, Rodolfo era o homem responsável por saudar os novatos, principalmente os nordestinos. Havia sido nomeado pelo Coletivo e cumpria muito bem seu papel de palestrante.

Nas escadas do Pavilhão, proferia a palavra, fazia esquemas e, em rápidas olhadelas, declamava todos os pontos fundamentais da reunião. Falava sobre a polícia sul-americana e possuía forte convicção de que a democracia iria vencer o fascismo.

Graciliano ficou espantado com aquele homem, pois seus discursos arrancavam lágrimas dos homens e das mulheres que presenciavam a declamação. 
"Esquisito um homem quase nu causar tal impressão" (RAMOS, 2008, p. 195) - foi dessa forma que Ramos construiu sua imagem dentro da narrativa: um homem baixo, a desfilar de cuecas e se equilibrar nos tamancos, porém, com postura forte, que atraía os olhares.

[...] Achava-se à vontade, a governar os nervos dóceis, consultando o papel da sinopse, dobrando para ocultar as linhas percorridas, movendo o lenço como se tirasse recursos dele. $O$ gesto de prestidigitador firme no seu ofício. Conservou-nos atentos meia hora, o prazo marcado para a conferência. Tê-la-ia, como depois notei, desenvolvido em sessenta minutos ou resumindo em quinze, expondo a matéria, sem esquecer um ponto. Capaz de, com destreza, analisar ou sintetizar. (RAMOS, 2008, p. 195 - 196)

Graciliano afirmara que não tinha nenhuma paciência para discursos, fossem eles curtos ou longos, mas os do Rodolfo Ghioldi o encantavam, conseguiam fixar sua atenção por mais de meia hora. Com esses atributos, Ramos fez questão de se aproximar do homem e observá-lo mais de perto. Ramos expõe a satisfação que sentia por estar em meio a pessoas como Ghioldi, com capacidade intelectual aguçada e isso the dava prazer em longas conversas, "[...] achava-me entre indivíduos importantes que me espicaçavam a curiosidade" (RAMOS, 2008, p. 192).

Quando Graciliano transferiu-se do cubículo 35 para o 50, a intimidade entre os dois cresceu, e Ramos passou a enxergar naquele homem uma espécie de esperança que, com suas palavras, espalhava a todos. Uma curiosidade é que Ghioldi não acreditava em quase nada do que ele proclamava para os presos, aquelas palavras eram para levantar o ânimo e não deixar a desesperança vencer, "ele sabia que Hitler, Mussolini, Franco e Salazar, bem como seus discípulos no governo brasileiro, ainda estavam longe de perder terreno" (MORAES, 2012, p. 124).

Entretanto, não deixava que isso transparecesse aos companheiros e, dessa forma, Ramos o construiu dentro da narrativa: homem forte, sábio, capaz de convencer a todos de que tempos melhores viriam. "E quando chegava $O$ 
desânimo, procurávamos Rodolfo Ghioldi, que tinha obrigação de ser forte, não podia fraquejar nunca" (RAMOS, 2008, p. 350).

Graciliano Ramos lamentou o fato de Rodolfo ter ficado abatido, magro e sem apetite, pois aquilo era um disparate para um homem forte.

Era Rodolfo que nos amparava no desânimo. [...] Enquanto ele discorria, eu the examinava as gengivas, banguelas, os dentes escassos. E zangava-me. Estupidez invalidar uma criatura assim, matar uma inteligência. Fraco e doente, Rodolfo nos animava. (RAMOS, 2008, p. 350)

Outra personagem que merece destaque dentro da narrativa e que, aos olhos de Ramos, ganha um novo significado durante o momento em que esteve preso foi Heloísa, sua mulher, que, aos 26 anos, aventurou-se para 0 Rio de Janeiro, em busca de ajuda e de possíveis soluções para que a prisão de Graciliano fosse solucionada.

Graciliano constrói Heloisa como uma personagem que sentiu as transformações que Ramos adquiriu com essa prisão, pois ele passou a enxergar não somente ela, mas o casamento em si com outros olhos.

No início da narrativa, Graciliano encarava o afastamento como uma espécie de dádiva, pois teria sossego para dar continuidade ao seu romance que estava em andamento e também ficaria longe da mulher que, segundo ele, era muito ciumenta e cujos ataques o irritavam.

[...] minha mulher replicava com estridência. Escapavame a significação da réplica, mas a voz aguda me endoidecia, furava-me os ouvidos. Não conheço pior tortura que ouvir gritos. [...] Minha mulher, porém, sentia-se lesada, o que me fazia perder os estribos. De repente um ciúme insensato. A incongruência me arrancava a palavra dura:

-- Que estupidez! 
Naquele momento a ideia da prisão dava-me quase prazer: via ali um princípio de liberdade. (RAMOS, 2008, p. 24)

Desde que fora preso, Graciliano ficou praticamente dois meses sem notícias ou qualquer tipo de contato com sua mulher. E aquela distância fazia com que Graciliano sentisse livre das responsabilidades de um pai de família. A prisão criava um mundo particular para Ramos: distante da mulher e de seus ataques de ciúmes, poderia aliviar a tensão que sentia quando estava junto dela. Um exemplo foi a despedida na estação da Great Western, em Maceió, onde o choro de Heloísa abalou a estrutura de Ramos e, por isso, ele considerava a visita dela como algo desnecessário, não queria piorar mais aquela situação.

Entretanto, Heloísa foi para o Rio de Janeiro e, antes da visita na prisão, enviou a Ramos um envelope que continha uma foto com seus filhos e escrevera também que estava no Rio e que iria visitá-lo. Logicamente, aquilo abalou Graciliano que achou um disparate uma mocinha criada em cidade pequena vir para o Rio, ainda mais sozinha.

No dia da visita, Graciliano contava as horas para ver Heloísa, arrumouse e foi encontrá-la. Após o longo abraço, começaram a conversar, e Heloisa informou a Ramos tudo que havia feito durante o período em que ficaram afastados. "As mulheres funcionavam como agentes de ligação, traziam notícias minuciosas, levavam relatórios, cartas, recados" (RAMOS, 2008, p. 272). Apesar de não concordar com todas as ideias e com a importância que Heloísa dava ao dinheiro, Ramos percebeu que era inútil discutir naquele momento e passara ver Heloísa com ternura, como alguém que não media esforços para ajudá-lo. Além disso, Heloísa mostrou ser uma mulher forte, capaz de enfrentar grandes desafios.

Naquele momento, os dissídios malucos distanciavamse, esbatiam-se, e as nossas relações se adoçavam. Inclinava-me a concordar, perceber na mulher energia e resolução, qualidades imprevistas a revelar-se na 
hora difícil. Pareciam-me estimar o perigo e o desconforto, dava-se bem com as mudanças, 0 movimento, possuía o instinto da direção, começava a gravar na cabeça o mapa do Rio, e isto era indelével. (RAMOS, 2008, p. 258)

Do incômodo inicial, Heloísa passou a ser vista por Ramos como uma verdadeira companheira, forte e disposta a enfrentar ao lado dele o período difícil da prisão. Ramos a caracteriza na narrativa como alguém que "cresce" e consegue ganhar espaço dentro das possibilidades que ele enxergava na época.

"As visitas de minha mulher durante algum tempo quebraram a monotonia da prisão e ligaram-me com inesperados laços ao exterior" (RAMOS, 2008, p. 272). Além disso, andava por todas as repartições, mesmo sendo leiga no assunto, procurava soluções para que Graciliano fosse solto.

\footnotetext{
Determinada a guerrear pela libertação do marido, Heloísa percorreu os Ministérios da Guerra e da Justiça, o Palácio do Catete e a Chefatura de Polícia em busca de dados sobre sua situação penal. Estupefata, comprovou a inexistência de qualquer acusação formal ou processo. (MORAES, 2012, p. $130-131)$
}

E assim, Graciliano manteve suas relações com Heloísa que, até o final da narrativa, foram vistas com companheirismo e admiração. "Para agradar Graciliano, Heloísa ia sempre arrumada, cabelos penteados e unhas feitas. Os dois haviam se reconciliado plenamente" (MORAES, 2012, p. 131).

Além de vários outros personagens que Graciliano destacou na narrativa por suas atitudes que, de alguma forma, foram nobres diante daquele cenário, Ramos também destacou aqueles que, de certa forma, eram "esquisitos" e chamavam a atenção.

A explicação disso é que Graciliano caracteriza a cadeia como uma espécie de fauna, em que os que habitavam ali ganhavam características de bichos, não somente pelo contexto que era imposto aos presidiários, mas pelas características que alguns companheiros dispunham. 
O português com "talento galináceo" foi um dos primeiros que Ramos ressaltou, com sua cantoria, imitando um galo, deixava todos em dúvida: "era um galo que estava ali?" Graciliano não entendia os motivos pelos quais aquela criatura imitava um galo constantemente, sempre repetindo a frase: "Por causa de uma aventura galante". Ramos classificou esse exercício como irritante, já que a repetição dos cocorocós era constante.

Estremeci ouvindo perto um canto de galo. Quem teria metido ali o animal? Procurei-o, guiando-me por outros cocoricós muito agudos. Percebi o engano. Lá em cima, um sujeito de bugalhos imóveis e expressão lorpa estirava o pescoço e esgoelava-se daquele modo. (RAMOS, 2008, p. 198)

Outro personagem que merece destaque nesse quesito é Agildo Barata - um dos dirigentes do Partido Comunista Brasileiro - caracterizado por Graciliano como "personalidade estranha". Era pequeno, possuía uma voz forte e cortante e viera para o Pavilhão dos Primários após a saída de uma leva de presos do Pedro I. Agildo vivia pelos cantos, juntamente com Sisson, outro personagem do Pavilhão dos Primários, sempre a elaborar pautas e longos resumos sobre as reuniões feitas no interior dos cubículos.

Com sua fala rígida, era muito perspicaz, usava seu poder de argumentação e "a sua força era interior" (RAMOS, 2008, p. 263), já que era contraditório um homem "minguado", quase sem músculos, exercer um poder de dominação em relação aos outros. Ramos, ainda, destaca que Agildo usava a palavra e o gesto certos e na hora propícia. A explicação que Ramos encontrou para a boa disposição discrepante de Agildo dentro do cárcere foi que esse sabia viver coletivamente, ignorava pequenas perturbações que eram desnecessárias e mantinha somente o que era essencial para sua sobrevivência dentro da prisão.

Agildo conseguia discernir a alma alheia. Individualmente isso não constitui nenhum dom especial. Em convivência prolongada, as caras das pessoas, uma ruga, piscadelas, sobressaltos, lábios contraídos, sorrisos, palidez, rubor, ligeiros sinais 


\begin{abstract}
quase instintos, conjugam-se, combinam-se com situações anteriores, oferecem-nos a instantânea percepção de sentimentos e pensamentos. Não se tratava disso. Pareceu-me que o sujeitinho moreno e exíguo possuía a qualidade rara de aprender num instante as disposições coletivas. (RAMOS, 2008, p. 264).
\end{abstract}

Apesar de sua força e de sua inteligência para lidar com a vida cotidiana do cárcere, Agildo era visto por Ramos como um sujeito estranho, de personalidade excêntrica e, por isso, Graciliano o classificou como um animal.

Além desses personagens, aparece a figura de Amadeu Amaral Junior, outro companheiro de Graciliano no Pavilhão. Ramos o caracteriza como um péssimo escritor de novelas que, por conhecer Graciliano, sempre Ihe pedia para que lesse e palpitasse sobre seus escritos. Como um animal, Ramos 0 relaciona com o pavão por ser arrogante, principalmente quando se tratava de literatura. "Amadeu Amaral Junior, ressentido e quase nu, a barba loura mais longa, a cueca mais escura, tinha rompantes ásperos, estridências de pavão, um grande pavão solitário" (RAMOS, 2008, p. 305).

Na prisão, o mundo constitui-se por um cenário limitado e desigual, sendo assim, qualquer possibilidade de fuga da realidade gera um impulso capaz de reverter sentimentos e modificar atitudes. Esses personagens que Graciliano expôs como animais servem para mostrar que dentro do cárcere qualquer fator ou atitude que os levassem além da realidade era válido.

Graciliano Ramos enxergava a vida no cárcere como sinônimo de produção de verdadeiros bichos humanos. A carência e a "liberdade" que a prisão proporcionava em relação a certos costumes, como, por exemplo, hábitos higiênicos e boas maneiras, para Ramos, permitiam aos presos uma vida irresponsável frente a esses fatores, livre de qualquer comprometimento. Esse quesito, para Graciliano, contribuía para que os presos virassem uma espécie de "bicho enjaulado". "Tínhamos essa liberdade. E havia outra. Andar nus, não escovar os dentes, falar à toa, admitindo ou recusando farrapos de noções obrigatórias noutra parte. ĺamos e vínhamos, perfeitos animais" (RAMOS, 2008, p. 355). 
Quando Graciliano Ramos foi transferido para a Colônia Correcional, na Ilha Grande, o ambiente repugnante e a forma rígida e desumana com que os carcerários eram recebidos assustou Ramos: "Essa mostra indecorosa, a falta da mínima dignidade, encheu-me de vergonha e medo" (RAMOS, 2008, p. 441).

A ideia de viver como bichos era mais relevante, pois as condições que Ihes foram apresentadas permitiam que o indivíduo que estava ali chegasse à total falta de dignidade humana que um ser humano poderia atingir. "Enfim todos nos animalizávamos depressa" (RAMOS, 2008, 507).

O mau cheiro, a falta de higiene, as péssimas instalações no galpão central - onde os presos ficavam quando não estavam trabalhando - a comida intragável que era comparada com as refeições dos porcos, o árduo trabalho em que os presos eram submetidos todos os dias (tinham que carregar pedras grandes e pesadas), a mistura de presos políticos com ladrões e assassinos e as práticas homossexuais dentro do cárcere foram alguns dos fatores que fizeram Graciliano pensar que a Colônia Correcional seria o lugar de sua morte. "Enfim não nos enganavam. Estávamos ali para morrer" (RAMOS, 2008, p. 434).

Em meio a essa realidade absurda, Graciliano Ramos apresentou mais dois personagens que foram muito significativos nesse contexto e que, apesar de pertencerem a mundos distantes, Ramos soube apreciar e enxergar 0 caráter de cada um.

Gaúcho foi um dos primeiros homens que Graciliano teve contato mais próximo dentro da Colônia. Ladrão assumido, não sentia vergonha de assumir seus erros, e ainda afirmava que aprendera os truques de arrombamento com sua mulher. Vendeu uma cama a Ramos que, na verdade, não pertencia a ele, mas sim aos doentes que ali estavam. Graciliano pagou 7 mil réis pelo leito. Essa venda, misturada pelas confusões do ladrão, proporcionou a Ramos um momento de alegria, contradizendo o contexto. "Fui tomar posse da cama; Gaúcho atrás, segurando a pequena bagagem, muito sério, representava 0 
papel de criado. Pus-me a rir, pela primeira vez me surgia ali motivo para riso" (RAMOS, 2008, p. 479).

Graciliano adorava escutar por horas as histórias de Gaúcho, realmente sentia prazer em ouvir as grandes aventuras que cercavam seus roubos e, por ser sincero, não sentir medo e nem vergonha de contar seus erros, Ramos enxergava nele um homem que, apesar de ser um ladrão, tinha índole.

\begin{abstract}
Gaucho [...] tinha aparência de uma ave de rapina. Estendeu-me a garra larga, acocorou-se junto à esteira, pôs-se a conversar naturalmente. Apertando-Ihe a mão, declarei ter muito prazer em conhecê-lo. Tinha. Não era apenas curiosidade. Finda a surpresa, confessei a mim mesmo que poderia tornar-me sem esforço amigo do ladrão. A firmeza, a ausência de hipocrisia, a coragem de afirmar, tudo revelava um caráter. (RAMOS, 2008, p. 425)
\end{abstract}

Cubano, outro personagem que Graciliano apresenta no contexto da Colônia Correcional, era um homem mediano, de fala mansa e que causava pavor nos encarcerados, pois, apesar de ser um ladrão, era próximo dos guardas e agia como tal. Os gritos horríveis de "formatura geral", os quais obrigavam os presos a ficarem em pé e em filas eram dele e independentemente do horário, os berros que ordenavam esse ritual eram constantes, levando os presos à exaustão, já que, às vezes, trinta e cinco formaturas eram organizadas em um só dia.

Contudo, essa impressão de homem ríspido e sem sentimentos que Cubano deixava transparecer foi mudada a partir do momento em que ele se aproximou de Graciliano. Ao perceber que Ramos não estava se alimentando e andava fumando muito, agiu de modo grosseiro, levantando a voz e exigindo que Ramos comesse.

--Seu fulano, entre em forma.

Voltei-me: 
-- Obrigado, não quero almoçar.

O negro estava diante de mim, decidido, sem nenhum vestígio das amabilidades ordinárias:

-- Não estou perguntando se o senhor quer, estou mandando. Entre na fila.

-- Tolice, Cubano, respondi com mau modo. Você não me dispensou das formaturas?

Essa réplica foi inútil: o moleque aproximou-se, cochichou-me ao ouvido, a voz trêmula:

-- Perdoe-me. Eu não posso deixar o senhor morrer de fome. Vai à força. (RAMOS, 2008, p. 506)

Essa atitude de Cubano fez com que Graciliano percebesse que, por trás daquela máscara de homem grosseiro, existia outro homem que possuía sentimentos. Assim, Graciliano o destaca como um indivíduo que estava ali para servir, já que, além disso, também estava preso, mas que, ao mesmo tempo, preocupava-se com a situação de alguns companheiros. Dessa forma, o desdém que Graciliano apresentou nos primeiros contatos que teve com Cubano foi transformado em afeição. "Amável serviçal, procurava tornar-nos a vida menos dura no lugar infame. [...] Tinha um coração humano, sem dúvida, mas adquirira hábitos de animal” (RAMOS, 2008, p. 507).

São inúmeros os nomes reais que aparecem como personagens ficcionais dentro de Memórias do Cárcere, indivíduos que foram observados por Graciliano, uns mais, outros menos, mas todos foram vistos com um olhar preciso, capaz de captar sentimentos que esses indivíduos traziam.

Como foi exposto anteriormente, Graciliano Ramos, além de se manter como ótimo observador e apreciador da consciência humana, manifestou-se como o narrador de sua própria trajetória dentro do cárcere, suportando situações inesperadas e desesperadoras que, por consequência, o fizeram trilhar um caminho árduo, porém verdadeiro, revelando as minúcias de um caráter exemplar que soube fazer do caos uma fonte de descobertas em relação a si mesmo e ao próximo. 
Dênis de Moraes, em sua biografia sobre Graciliano Ramos, soube explicar exatamente o que significou a passagem de Ramos, não somente pelo Pavilhão dos Primários, onde o contato com as pessoas foi mais íntimo, mas em toda sua história dentro da cadeia:

Por trás do Graciliano introvertido, a vagar de pijama, silencioso, pelos corredores, estava um arguto observador da espécie humana confinada no Pavilhão dos Primários. Com olhos de lince, fixou personagens e sensibilidades. Apreendeu, no mundo infame do presídio, dramas, aspirações, frustrações e destroços, ocultos ou visíveis. Como se fosse um rastreador da alma alheia, averiguou palavras e gestos, cortejou reações, dissimulações e verdades. (MORAES, 2012, p. 125)

Analisar Memórias do Cárcere significa adentrar ao mundo particular de Graciliano Ramos, poder constatar seus medos, angústias, defeitos, alegrias e seu comprometimento com a Literatura. A resistência e o engajamento foram armas presentes no momento de perturbação social e psicológica, o qual deixa evidente sua índole de homem honesto e que, mesmo sendo moldado pelo sistema da época, não se deixou influenciar pelos hipócritas.

Graciliano Ramos e seus personagens reais, contados e detalhados pela visão de um homem que, ao mesmo tempo em que via a miséria do ser humano, também souber distinguir caracteres e qualidades boas que trouxeram à tona indivíduos que estavam mergulhados no desatino social da época.

Só conseguimos deitar no papel os nossos sentimentos, a nossa vida. Arte é sangue, é carne. Além disso, não há nada. As nossas personagens são pedaços de nós mesmos, só podemos expor o que somos." Graciliano Ramos (Carta à irmã Marli Ramos. 23 de novembro de 1949) 


\section{CAPÍTULO II: O EMPAREDAMENTO SIMBÓLICO (A ESCRITA)}

\section{1 - LIBERDADE}

Quando Graciliano Ramos saiu da prisão, na manhã do dia 13 de janeiro de 1937, o mundo se abria novamente para ele, trazendo uma perspectiva positiva, pois a tão sonhada liberdade estava ali, nascendo outra vez e sendo vivida. Mas, para Ramos, sua saída simboliza outro sentimento: o desespero.

Pode parecer contraditório, mas não deixa de ser coerente. Graciliano se viu perdido e aflito quando se deparou com as portas da Casa de Correção abertas e a rua estava ali, as pessoas, a família que o esperava, enfim, o mundo estava de volta.

Por ser um ex-presidiário, o medo e a certeza de que não seria aceito na sociedade novamente, principalmente na literária, talvez fosse o que mais lhe afligia.

\footnotetext{
Era absurdo confessar o desejo de permanecer ali, ocioso, com receio de andar nas ruas, tentar viver, responsabilizar-me por qualquer serviço. Longo tempo me esforçara por justificar a preguiça: todos os caminhos estavam fechados para mim, nenhum jornal me aceitaria a colaboração, inimigos ocultos iriam prejudicar-me. Escasseavam agora as evasivas covardes. (MORAES, 2012, p. 149)
}

Esse medo social o levou a constatar apenas uma certeza inicial: não pretendia e não queria voltar a Alagoas, seu estado natal. Os motivos eram realçados pela agonia que ainda o cercava quando se lembrava dos dias horríveis de perseguições que passou dias antes da prisão. Imaginava também a trágica repercussão que seus meses na cadeia provocaram em seus amigos e até familiares alagoanos, já que de dentro da prisão acompanhava algumas notícias que foram publicadas a seu respeito. "Não faltavam vozes a excomungá-lo pela fama de comunista. E houve, em Palmeira dos Índios, 
quem mandasse queimar livros seus, com medo de represálias" (MORAES, 2012, p. 150).

O sentimento por Alagoas, após a saída do cárcere, foi constituído por uma dualidade avessa: às vezes Graciliano sentia nostalgia e elogiava seu estado natal, colocando Alagoas como um dos melhores lugares do mundo, pois era o seu lugar. Outras vezes, Ramos a chamava de "terra chinfrim", com raiva e más recordações.

Os resquícios da prisão também eram visíveis em Graciliano. O cabelo bem mais grisalho e o corpo magro denunciavam os meses de sofrimento. Mas, apesar disso, a vida não podia parar e Ramos sabia que seu maior desafio era sustentar a família, a qual, em partes, também vinha morar no Rio de Janeiro.

Graciliano não gostava da ideia de escrever por obrigação para que pudesse conseguir dinheiro, mas era questão de necessidade e ele entendia isso. $\mathrm{E}$ o medo de não conseguir pagar um lugar decente para morar com a família e colocar comida na mesa contribuíram para que Graciliano voltasse a escrever e, com isso, recuperasse o prestígio social e ganhasse dinheiro também.

Mas, enquanto isso não acontecia, Ramos contou com a ajuda de grandes amigos, como o escritor, também nordestino, José Lins do Rego, o qual manteve uma amizade franca até os dias que antecederam sua morte.

José Lins do Rego foi um dos grandes incentivadores para que Ramos voltasse à ativa, sempre o enaltecia com seus elogios sinceros e o encorajou a se inscrever para o concurso de literatura infantil do MEC, colaborando, assim, para que Ramos escrevesse a obra $A$ terra dos meninos pelados, a qual permitiu que Graciliano vencesse o concurso em setembro de 1937.

José Lins também influenciou e introduziu Graciliano Ramos na intelectualidade brasileira. Os dois participaram das frequentes reuniões na livraria José Olympio, ponto de encontro dos intelectuais cariocas, onde 
conheceram e ampliaram suas amizades, o que permitiu também a Ramos possibilidades maiores de conseguir trabalho.

As dificuldades financeiras acompanharam Ramos até os últimos meses de sua vida. Viver de literatura não era fácil, pagava-se pouco, o reconhecimento tardava e a situação também não favorecia ainda mais nas condições políticas em que o Brasil se encontrava no final da década de 30.

As preocupações de Graciliano aumentaram quando Heloísa, sua esposa, com as duas filhas, Clara e Luiza, vieram para o Rio de Janeiro. A vida difícil de um escritor e ex-preso político não contribuiu para que as necessidades diárias, como aluguel, comida e despesas em geral fossem banidas.

Essa realidade minguada, por muitas vezes, fez com que Graciliano pensasse em desistir da Literatura e procurar emprego que realmente lhe desse dinheiro. Na maioria das vezes, eram Heloísa e José Lins que o reanimavam para que pudesse seguir em frente. Certa vez, Graciliano desabafou em uma carta para o escritor Dalcídio Jurandir, em 1939, como Dênis de Moraes mostrou em sua biografia:

Não nos enriquecemos nem entraremos na Academia, mas estou certo de que morreremos de pressa. Em todo o caso, continuamos a trabalhar, nem sei para quê. Estou com vários livros começados, todos ruins. É possível que não chegue a concluir nenhum, vou entregando pedaços deles nos jornais, porque enfim preciso viver. Nestes últimos meses tenho levado uma vida muito semelhante a do meu Luís da Silva, um pouco pior que a dele. Talvez esta medonha encrenca determine um pouco deste pessimismo. Que quer você? Não consigo separar as minhas desgraças miúdas das obras, as grandes, e o resultado é este: vingo-me na literatura, que até hoje só tem rendido aborrecimentos, prisões, inimigos, calúnia... (MORAES, 2012, p. 171) 
Apesar do desânimo que atingia Ramos, ele não deixou de produzir seus escritos, os quais, nessa época, foram produzidos para que conseguisse sustentar a si próprio e sua família também. Assim, mais ou menos três meses após sua saída da prisão, escreveu o conto "Baleia", com o seguinte pensamento: "será que há mesmo alma em cachorro?"

Em seguida, escreveu também os outros contos pertencentes a Vidas Secas, um romance com contos que poderiam ser lidos separadamente, já que Graciliano escrevia os contos e entregava aos jornais para que pudesse ganhar dinheiro mais rápido. Após a junção dos capítulos, o livro foi publicado e, em plena época de crises e conturbações sociais e políticas, Graciliano conseguiu prestigio e reconhecimento em meio à intelectualidade brasileira. Com os objetivos da obra, Graciliano destacou: "o que me interessa é o homem, o homem daquela região aspérrima. Julgo que é a primeira vez que esse sertanejo aparece em literatura" (MORAES, 2012, p. 159).

Com isso, as glórias literárias começariam a envolver Graciliano. A revista Acadêmica, a qual se dedicava a publicar ideias antifascistas e defender posições de vanguardas, dedicou uma de suas edições a Graciliano Ramos. Graciliano, como ainda não tinha nenhum vínculo partidário, se sentiu retraído, pois não queria mais problemas políticos. Mas, como era simpatizante das ideias antifascistas, não impediu que a revista fosse publicada.

Além disso, Ramos também participou do manifesto "Os intelectuais brasileiros e a democracia espanhola", o qual assinalou como uma de suas primeiras manifestações públicas depois da saída da prisão. Enfim, a vida, apesar de difícil e cruel, ia voltando ao normal, e a literatura, cada vez mais, presente nos dias intermináveis que refletiam uma sociedade conturbada em meio à ditadura. 


\title{
2.2 - O ENVOLVIMENTO COM O PCB
}

Em 1941, o Partido Comunista Brasileiro começou a se reorganizar depois do grande fracasso com a Revolta Comunista em 1935. Como muitos aliados do partido estiveram presos até o final da década de 30 , o partido sofreu um abalo, entrou em decadência, mas, aos poucos, foi se reerguendo.

Grandes nomes da intelectualidade brasileira passaram por ele e conseguiram disseminar as ideias comunistas por meio de suas representações artísticas ou políticas. Assim, apesar do partido ter vivido muitos anos na clandestinidade, ele conseguiu sobreviver às imposições repressivas da direita.

\begin{abstract}
Esta peculiaridade deriva do relacionamento especial que manteve com a intelectualidade e o mundo da cultura e dos laços que seus artistas e intelectuais mantiveram com a sociedade, prioritariamente em seus ambitos específicos de atuação. (FERREIRA, 2012, p. 13)
\end{abstract}

E, como a maioria da intelectualidade da época não consentia a aproximação de Getulio Vargas com a Alemanha Fascista, o partido começou a ganhar aliados, tanto políticos, como intelectuais e artistas. O crescimento foi tão simbólico que, em 1945, o PCB conseguiu se tornar legal, conquistando assim seu registro eleitoral.

Os grupos que pertenciam ao PCB apoiavam as causas democráticas, nacionais e antifascistas que eram reprovadas pelo governo de Getúlio Vargas. Em 1944 e 1945, a ditadura começou a entrar em decadência e, com ela, o Estado Novo. Consequentemente, o grupo esquerdista ganhou forças e ajudou a derrubar o sistema governamental da época. Com certeza, a atividade intelectual foi uma das responsáveis para que isso acontecesse: "nunca se conspirou tanto como naquele fim de 1944 e início de 1945" (MORAES, 2012, p. 202).

Graciliano Ramos não tinha qualquer ligação direta com o PCB, mas apoiava as causas nacionalistas e, principalmente, as antifascistas. Como 
frequentava as reuniões na livraria José Olympio e bares em que intelectuais e comunistas se reuniam, a proximidade de Ramos com o partido tendeu a aumentar. Sua amizade longa e próxima com o pintor Cândido Portinari também contribuiu para que Ramos, em 1945 se filiasse ao Partido Comunista Brasileiro.

A filiação ao partido, para muitos, foi tardia, visto que Ramos já estava praticamente inserido nos ideias comunistas que o partido alegava. Entretanto, ele se explicava defendendo o pensamento de que serviria um escritor nordestino no partido sem nenhum interesse político e ainda afirmava: "não sei guerrear, porque minha arma é a pena". [...] "Eu fiquei tão espantado, porque nunca pensei que pudesse ter valia como militante" (MORAES, 2012, p. 205).

$E$ teve. Os membros do PCB enxergavam a adesão de Ramos ao partido como um prêmio. Obviamente, era um prêmio, sim. Ramos estava no auge, consagrado com suas obras anteriores, principalmente com Vidas Secas, e a crítica exposta em seus textos era bem-vista pelos integrantes do partido, 0 que permitiu que mais simpatizantes se filiassem ao grupo.

Mas sua trajetória dentro do partido nem sempre foi satisfatória e compensadora. Na verdade, o que os comunistas queriam era usar a literatura de Graciliano, que era vista como exibicionista dos problemas sociais brasileiros, para fazer uma espécie de propaganda dos ideais defendidos por eles.

Os membros do PCB idealizavam uma literatura panfletária com caráter de realismo - socialista que divulgasse e defendesse as ideias comunistas vindas da União Soviética e disseminadas no Brasil.

Graciliano não aceitou a proposta de refazer seu modo de escrever, pois elementos que não eram seus e que distorciam suas características deveriam ser incorporados à escrita. Dessa forma, muitos intelectuais se viram à mercê das decisões impostas do partido, o que acabou balançando a estrutura partidária. "O intelectual, por mais solidário que fosse às lutas sociais e às causas dos oprimidos, não poderia sufocar suas inquietações diante do mundo, 
nem se conformar que lhe indicassem as ferramentas de seu ofício" (MORAES, 2012, p. 251).

Esses impasses dentro do partido enfraqueceram as relações de Graciliano Ramos com as ideias comunistas e, não somente Ramos se sentiu pressionado, mas outros membros também não aceitavam essas imposições de 'vender' propaganda por meio da literatura. Os grandes intelectuais que faziam parte do grupo não precisavam dele para se promover, pois o respeito já estava imposto diante do público. Assim, podem-se citar nomes, além de Graciliano, como Aníbal Machado, Di Cavalcanti, Astrojildo Pereira, Cândido Portinari, entre outros que exerciam diferentes atividades.

E assim Graciliano seguiu sua trajetória no PCB, mas sempre afirmando e reafirmando que o compromisso com a literatura era social e que esse comprometimento social não poderia ser atropelado por imposições ideológicas incompreensíveis. Dessa forma, Ramos nunca aprovou uma literatura que se baseasse na panfletagem, na qual o escritor deveria enaltecer e ser porta-voz de grupos de pressão política. Então, se a política dominasse a literatura, a única certeza era de que essa iria morrer.

\footnotetext{
"Eu não admito literatura de elogio. Quando uma ala política domina inteiramente, a literatura não pode viver; pelo menos até que não haja mais necessidade de coagir, o que significa liberdade outra vez. O conformismo exclui a arte, que só pode vir da insatisfação". (apud RAMOS; MORAES, 2012, p. 198)
}

Em 1947, o Partido Comunista Brasileiro perdeu seu registro eleitoral e voltou à clandestinidade, visto que a nova Constituição proibia a existência de partidos que fossem contrários às ideias do governo. Assim, O PCB perdeu forças em relação ao contexto político e social da época e, consequentemente, o número de filiados também. Apesar disso, Graciliano se manteve ligado ao grupo. 


\section{3 - MEMÓRIAS DO CÁRCERE - A ESCRITA}

Creio que não servi direito: por circunstâncias alheias à minha vontade, fui remetido para o Rio de maneira bastante desagradável. Percorri vários lugares estranhos e conheci de perto vagabundos, malandros, operários, soldados, jornalistas, médicos, engenheiros e professores da Universidade. Só não conheci o delegado de polícia, porque se esqueceram de interrogar-me. Depois de onze meses abriram-me as grades, em silêncio, e nunca mais me incomodaram. Donde concluo que a minha presença aqui não constituía perigo. (Trecho ${ }^{4}$ de uma carta escrita por Graciliano Ramos a Getúlio Vargas)

O desabafo de Graciliano Ramos na carta, a qual nunca foi entregue a Getúlio Vargas, reflete bem um dos motivos que o levaram a iniciar os escritos de Memórias do Cárcere, mesmo que dez anos após sua saída da prisão.

Em 25 de janeiro de 1946, Ramos decidiu iniciar a história que contaria os meses sofridos e intermináveis em que passou dentro de algumas penitenciárias e batalhões no ano de 1936 e início de 1937.

O motivo inicial pelo qual Ramos optou por relatar os acontecimentos da prisão foi a dificuldade financeira que sempre esteve presente, principalmente depois que saiu da cadeia e passou a morar no Rio de Janeiro com a família. Assim, escrever o livro significava ganhar dinheiro e amenizar os problemas financeiros que enfrentava. Além disso, apesar da prisão pertencer ao passado, Graciliano nunca esqueceu as lembranças amargas que os meses encarcerados proporcionaram a ele e ainda restava a indignação por uma prisão, aparentemente, sem motivos concretos.

Em 13 de maio de 1946, Ramos escreveu para Benjamin de Garay: "Tenho um bom assunto, uns tipos curiosos, e acho-me na obrigação de aproveitar o material que o governo me ofereceu". Essa citação disposta na biografia de Graciliano Ramos por Dênis de Moraes (2012, p. 216) mostra que

\footnotetext{
${ }^{4}$ Disposto em: O velho Graça - Dênis de Moraes, 2012, p. 172.
} 
Ramos tinha a intenção de levar ao conhecimento do público como era a vida de um preso político na época do Estado Novo.

E o assunto realmente rendeu muitas histórias para o livro novo. Em pouco tempo, Graciliano conseguiu listar inúmeros nomes de pessoas que conviveram com ele durante a prisão em diversos lugares. Começou também a anotar os principais pontos que as lembranças lhe permitiam.

O que afligia Graciliano era a questão de trabalhar com personagens que estavam vivas e que iriam se ver dentro da obra com suas qualidades e fraquezas; sendo assim, Graciliano, no início, hesitou por questões de privacidade. Um exemplo disso foi Agildo Barata, na época tesoureiro do PCB e ex-companheiro de cárcere de Graciliano nos meses em que passaram no pavilhão dos primários.

No livro, Agildo é um personagem que se destaca pelas suas ações estranhas, como passar horas escrevendo e resumindo as reuniões dos cubículos, além de parecer, para Graciliano, um homem insignificante que só conseguia se safar de situações ruins porque reclamava demais. Mas, Ramos também não deixa de destacar sua força e coragem para vencer os impasses que a prisão oferecia.

Assim, mesmo antes de ler a obra, Agildo se incomodou com a situação de ser um dos personagens do livro de Graciliano.

--- O Graciliano está pintando um retrato ridículo meu.

Mercadante discordou:

--- Agildo, eu li esse capítulo e posso lhe assegurar que não tem nada de ridículo; pelo contrário, o Graça acentua um aspecto seu: você é uma pessoa de baixa estatura, com aparência frágil, mas de grande força, a ponto de serem necessários três guardas para contê-lo durante um protesto na cadeia. (MORAES, 2012, p. 263)

Outro fator que atormentava Ramos e fez com que a obra paralisasse por um tempo foi a possível censura que o governo faria sobre o livro. Muitas 
pessoas não tinham conhecimento da vida carcerária naquela época, e muito seria denunciado sobre o governo de Getúlio Vargas, principalmente as diversas prisões descabidas que prosseguiram sem acusação formal e até mesmo sem interrogação, como era o caso de Graciliano.

Mas as carências que a família de Graciliano enfrentava na época foram mais fortes e o obrigaram a escrever e a se comprometer com José Olympio, dono da editora mais consagrada da época, o qual que prometeu a Ramos um salário mensal para que ele escrevesse e entregasse, pelo menos, três capítulos por mês, num prazo de três anos.

Ramos aceitou a proposta, apesar de não apreciar a ideia de escrever por obrigação. Ele queria sim contar os entrechos que viveu na cadeia, mas não dessa forma. Assim, o que seria concluído em três anos, foi lentamente construído em seis anos. Esses anos de trabalho árduo, apesar do cansaço, da confusão política pela qual passava por meio do PCB e das dificuldades financeiras e familiares, não atrapalharam o grande escritor que Graciliano mostrou, mais uma vez, ser.

"Durante os seis anos dedicados a Memórias do
Cárcere, Graciliano se comportou como um soldado da
escrita. Quase diariamente estava frente a frente com a
exumação das vivências dolorosas nos soturnos
xadrezes da ditadura. [...] O processo de composição
seria mais vagaroso do que o habitual, porque
importava em vasculhar previamente o baú de
lembranças atordoantes". (MORAES, 2012, p. 218)

E, assim, lentamente, Memórias do Cárcere foi surgindo em meio à Literatura. Uma história que transbordava, por meio de um narrador consciente de si, porém atrapalhado com as memórias que vinham e, ao mesmo tempo, se confundiam com o tempo longínquo.

Obviamente, por Graciliano Ramos pertencer ao PCB, a interferência do partido na obra era evidente. Diógenes Arruda, na época membro do comitê do partido, pediu que Ramos fizesse algumas alterações em determinadas passagens, de forma que a obra fizesse uma apologia ao realismo socialista 
que o partido pregava. Ramos, realmente ficou chateado com o pedido e sua resposta foi prática e serena: não mudou absolutamente nada do já havia escrito.

E, em setembro de 1951, já com problemas de saúde bem visíveis, Graciliano parou de escrever, faltando apenas um capítulo para a conclusão total da obra.

Durante a escrita, Graciliano se deparou com um cenário confuso à sua volta. A vida no Rio de Janeiro nunca seria comparável aos momentos em que passou em Alagoas. $O$ estado alagoano tinha um fator que nenhum outro lugar possuía: era o seu lugar, a sua terra e suas origens estavam lá. Mas, impossibilitado de vivenciar aqueles momentos novamente, Ramos passou a enxergar Alagoas como um lugar que Ihe trazia recordações tristes que antecederam os momentos da prisão.

Outra questão que Ramos enfrentou durante a escrita de Memórias do Cárcere foi seu ingresso e permanência no Partido Comunista, o qual the trouxe benefícios e grandes amizades, mas também chateações, como o desentendimento com José Lins do Rego, grande amigo de Ramos e o qual não concordou com a filiação ao partido.

Graciliano Ramos também passou por problemas financeiros gravíssimos, chegando ao ponto de aceitar ajuda dos amigos do PCB. Os problemas pessoais não se resumiram apenas em dinheiro, pois, em 1950, Márcio, um dos filhos de Graciliano, acabou se suicidando por motivos psicológicos em 30 de agosto deste mesmo ano, o que levou Graciliano a um desânimo profundo.

A descoberta de um câncer no pulmão também contribuiu para Ramos se atrapalhasse ainda mais com as escritas. A impossibilidade de tratamento no Brasil, as dificuldades financeiras e os abalos emocionais eram motivos suficientes para que a obra não saísse.

Mas, mesmo que incompleta, Memórias do Cárcere foi publicada sem nenhuma interferência política na obra. Tudo que Graciliano escreveu a 
respeito dos meses em que passou encarcerado não possui nenhum teor panfletário, com tendências a vangloriar algum nome ou líder.

Os personagens reais da obra aparecem como realmente eram, seres humanos que estavam sofrendo com a época opressora e conturbada. Não há indícios de que Ramos tentou colocar as ideias do partido dentro da obra, pois ele se limitava apenas a contar o que aconteceu por entre as paredes daqueles cubículos. Ramos não se preocupou em expandir o conteúdo do livro para tratar de questões ideológicas. Ele apenas se prendeu na observação e compreensão das atitudes e comportamentos de cada um que conviveu com ele diante daquela situação.

A preocupação de Graciliano era com o aspecto humano e não com o enaltecimento de algumas pessoas. Isso fica muito evidente nas primeiras passagens de Memórias do Cárcere em que, também, Ramos já pressente que a publicação do livro será póstuma:

Procurei observá-los onde se acham, nessas bainhas em que a sociedade os prendeu. A limitação impediu embaraços e atritos, levou-me a compreendê-los, sentilos, estimá-los, não arriscar julgamentos precipitados. E quando isso não foi possível, às vezes me acusei. Serme-ia desagradável ofender alguém com esta exumação. Não ofenderei, suponho. E, refletindo, digo a mim mesmo que, se isto acontecer, não experimentarei o desagrado. Estou a descer para a cova, este novelo de casos em muitos pontos vai emaranhar-se, escrevo com lentidão - e provavelmente isto será publicação póstuma, como convém a um livro de memórias. (RAMOS, 2008, p. 13)

O narrador de Memórias do Cárcere, nas décadas de 40 e início de 50, é um homem abatido pelos problemas que uma vida cheia de idas e vindas, carências e inconformismos diante da realidade the proporcionou. Porém, Ramos se mostra consciente e, mesmo que por obrigação, sabia que a escrita daquele livro o faria passar para o papel o sentimento de raiva e indignação que ainda revivia. 
Memórias do Cárcere mostra o compromisso que Ramos tinha com o social, dessa forma, a literatura que Graciliano produzia era do povo e para o povo, a qual não se limitava também às mazelas do mundo, mas também à tentativa de entendimento do ser humano, mesmo que em suas vivências mais obscuras.

Com certeza, não somente Memórias do Cárcere, mas toda sua obra é um reflexo de suas experiências, desejos e concretizações. É impossível separar a carreira literária de Ramos de sua vida pessoal, uma completa a outra e, se não fosse assim, Ramos, talvez, não seria o exemplo de homem, intelectual e militante que foi; manteve seu caráter de homem digno e fiel a seus princípios acima de qualquer pessoa ou situação.

Ricardo Ramos ilustrou bem o reflexo de Memórias do Cárcere na sociedade:

\begin{abstract}
"Memórias do Cárcere incomodou e irritou porque o velho preservava a sua independência intelectual. Incomodou e irritou pela crítica ao movimento de 35 , visto como quartelada; pelo militarismo dos tenentistas que tinham aderido depois ao partido; pelas contradições que ele mostrou dentro da prisão [...]; pela compreensão que tinha da situação dos presos comuns e de certos policiais, o que fugia ao esquematismo, pois apresentava a polícia como instrumento de dominação e os presos como pobres-diabos, humanizando-os". (apud RICARDO RAMOS; MORAES, 2012, p. 263)
\end{abstract}

Quando a Literatura se distancia da realidade, ela fica desfocada em relação ao que o homem deseja, tanto as mudanças sociais quanto as políticas. Sendo assim, ela não se ocupa em atender as preocupações humanitárias, mostrando apenas um lado bom e enfeitado do mundo.

Graciliano sempre defendeu a literatura que adentrava os impasses que marcavam vidas e sociedades e não se hesitava porque, talvez, a obra ficasse desagradável. Seu compromisso era ser desagradável sim, mas nunca infiel à sua vontade de revelar um Brasil que sofria por ser tão dependente de fatores 
externos. Esse mesmo país se esquecia de seu povo, pois este merecia 0 enfoque de toda sua escrita. E Memórias do Cárcere prezou por isso. 


\section{CAPÍTULO III}

\section{ANÁLISE - A SIMETRIA ENTRE O INTELECTUAL PROPOSTO POR EDWARD SAID E O INTELECTUAL APRESENTADO POR GRACILIANO RAMOS EM MEMÓRIAS DO CÁRCERE}

Alicerce: talvez seja essa a palavra que melhor resuma o papel de um intelectual dentro de uma sociedade. Representar, como tarefa intelectual, é trabalhar com os fatos e dirigir pensamentos e ideias comuns a uma coletividade, e, ao mesmo tempo, tentar acentuá-los como formas para o bem coletivo da mesma.

Por isso, a intelectualidade não pode ser vista como um simples mecanismo, ela deve ser vista como uma solução que precisa ser desenvolvida e planejada. Entretanto, esse conjunto de caracteres não se desenvolve espontaneamente. O intelectual moderno proposto por Edward Said busca a intelectualidade de forma vigente, precisa e destaca aqueles que, de alguma forma, estão ativos na sociedade, enfrentando problemas sociais e expostos a qualquer tipo de alteração no cenário político-social.

É interessante pensar em como se pode agregar as ideias e levantamentos de Edward Said sobre o intelectual e associá-los a Graciliano Ramos, mais especificamente, no contexto de Memórias do Cárcere.

A ligação entre os dois intelectuais é bem realçada, pois mesmo pertencendo a países diferentes e culturas distintas, defenderam causas que, superficialmente, não se ligam, mas, em uma análise mais profunda, tanto Said quanto Graciliano lutam a favor de uma mesmo ideal: dar voz e tentar amenizar os problemas que afetam seu povo.

Essa análise tem o objetivo de encontrar os pontos que se interlaçam e alguns que se distanciam entre os dois intelectuais. 


\subsection{O EXÍLIO}

A primeira questão que deve ser levantada em relação às semelhanças e diferenças entre Said e Ramos em Memórias do Cárcere são as ideias que correspondem ao intelectual que está exilado, no caso de Said ou privado de sua liberdade, como se configura em Graciliano.

Para Edward Said, os intelectuais exilados são pessoas que obtêm um conhecimento maior dos fatos ao seu redor, além de conseguirem perceber os motivos e ações que os levaram a chegar a determinado contexto, "porque o exilado vê as coisas quer em termos do que deixou para trás, quer em termos do que de fato está aqui e agora, há uma dupla perspectiva, que nunca encara as coisas isoladamente" (SAID, 2000, p. 59-60).

Essa dupla perspectiva citada por Said revela como acontece a construção do discurso desse indivíduo que está exilado do seu lugar natal e que diante dos fatos atuais consegue distinguir e perceber os fatores que 0 levaram até esse ambiente. Consequentemente, o discurso do intelectual exilado será moldado por um lócus enunciativo concreto e permeado por uma dualidade: a realidade e o passado. Contendo, assim, características que remetem tanto à nova vida, quanto à que ficou para trás.

É justamente por isso que, praticamente, toda a obra de Said contém seu discurso de exilado, dividido entre a vida de cidadão americano e os resquícios da vida oriental deixada para trás quando adolescente.

O exílio de Said não permitiu que ele enxergasse a atividade intelectual em relação à causa palestina de uma forma somente racional. Said era sensível à causa justamente por ser um palestino e ter saído de seu país muito cedo; sendo assim, não pôde vivenciar de perto as dificuldades enfrentadas pelo seu povo.

Por isso a luta a favor dos palestinos, como se ele ainda fizesse parte daquele cenário. Mesmo nos Estados Unidos, sua luta foi constante para que de alguma forma pudesse ajudar a causa que tanto defendeu. 
Said representa a condição de exilado como uma espécie de privilégio, de sabedoria e de momento oportuno para reflexão. Nessas condições, o exilado consegue manter um distanciamento da realidade que o cercava, observando diretamente todas as influencias que sofria, juntamente com os fatos que the eram impostos. "Quanto mais somos capazes de deixar nosso lar cultural, mais facilmente somos capazes de julgá-lo e também ao mundo inteiro, com o distanciamento espiritual e a generosidade necessários para a verdadeira visão" (SAID, 2007, p. 348). E foi exatamente por estar exilado que a causa palestina para Said não era vista simplesmente como um rearranjo de terras e fronteiras, era mais que isso.

Assim, a carreira literária, acadêmica e crítica de Said só foi concretizada porque ele soube encarar o exílio como algo desafiador, estimulante e propício para que suas ideias fossem divulgadas a favor do cenário desolador que deixou para trás na Palestina.

Porém, Said reforça que a condição de exilado só foi vista como algo benéfico no decorrer do século $X X$, visto que em tempos pré-modernos, os exilados eram associados a anos de desespero e castigos intermináveis, sem proveito algum desse tempo de ausências.

Mas, apesar de ser um período de carências, o intelectual não enxerga essa estação como algo desfavorável à sua vida, mas como início de um momento temporário, com possibilidades de novos caminhos, mesmo que esses não sejam totalmente agradáveis, mas razoáveis e flexíveis. Como fica exemplificado na trajetória de Said nos EUA; um trajeto marcado por estudos e fortalecimento da carreira, mas também pautado por divergências de ideias e surgimento de muitos inimigos.

Com Graciliano Ramos no contexto de Memórias do Cárcere foi diferente. Graciliano estava preso, foi forçado a deixar sua liberdade, sua terra e tudo que usufruía dela. A privação dessa liberdade é vista de forma diferente do exílio revelado por Said. A prisão era o afastamento, talvez, da família, do trabalho, mas não do país e da situação política que o envolvia. 
Diferente do exílio que Said narra como ponto positivo para as reflexões e entendimento das sociedades, a prisão proporcionou a Ramos momentos em que a loucura se avizinhava da realidade e essa 'provável' insanidade manteve-se paralela ao desejo de adaptação, conservando a necessidade de escrever para que os pensamentos que estavam desordenados e incoerentes se reorganizassem em sua mente. Essa loucura está inserida nos primórdios da vida no exílio, no caso, da prisão que, como Said explica, é perturbadora e contraditória.

O que Ramos encarava como desafio era a adaptação forçada dentro do ambiente carcerário, além de aprender a conviver com pessoas diferentes, incluindo assassinos, ladrões e outros presos políticos. Assim, o desespero que a cadeia gera pode ser confrontado pelo estímulo que o exílio proporciona.

Nos primeiros momentos do cárcere de Ramos, ele se sentiu estimulado pela vida diferente e nova que o afastamento iria proporcionar a ele: "Aquela viagem era uma dádiva imprevista. Estivera a desejá-la intensamente, considerando-a difícil, quase irrealizável, e alcançava-a de repente" (RAMOS, 2008, p. 35).

Edward Said afirma que é comum o intelectual sentir-se feliz com a situação do isolamento. Isso acontece porque esse indivíduo passa a enxergar esse estado como posição conveniente, visto que essa condição favorece a liberdade e o conhecimento.

A felicidade que Graciliano Ramos expressava com a ideia de se manter afastado justificava-se pelo momento contraditório pelo qual sua vida profissional e familiar se encontrava. Não era um momento oportuno para deixar a vida estática; porém, para ele, sua atitude foi justificada pelo contexto, visto que a prisão para Ramos passou a ser encarada como uma espécie de descanso daqueles gritos e descontroles financeiros e emocionais. 
[...] Na verdade suponho que me revelei covarde e egoísta: varias crianças exigiam sustento, a minha obrigação era permanecer junto a elas, arranjar-Ihes por qualquer meio o indispensável. [...] Com fraqueza, desejei que na acusação houvesse algum fundamento. E não vejam nisto bazófia ou mentiras: na situação em que me achava justificava-se a insensatez." (RAMOS, 2008, p. 24)

Outra questão que Said reforça é que o intelectual representa uma constante busca pelo novo e o exílio proporciona essa perspectiva, de viver uma vida sem previsibilidade, sem sustentação, com possibilidades de transformações a todo o tempo. Isso leva o intelectual a se interessar pelo desconhecido. Consequentemente, esse caminho passa a surpreender 0 intelectual que se encanta com a ideia do imprevisto a qualquer momento.

O prazer de ser surpreendido, de nunca tomar nada por
certo, de aprender a desvencilhar-se em circunstâncias
de instabilidade vacilante que confundiram ou
assustariam a maior parte das pessoas. Uma vida
intelectual é, acima de tudo, conhecimento e liberdade." (SAID, 2000, p. 59)

Para Said, a condição do exilado é metafórica, no sentido de depender de todo o processo histórico-social que o levou até o isolamento. Dessa forma, o resultado da atividade intelectual no período de afastamento depende da condição social e política da realidade que o cercava antes do exílio.

Um desses resultados da atividade intelectual durante o período de exílio é a questão da acomodação ou não em seu novo habitat, o que, para Said, não chega a ser realmente um problema, mas uma questão de estilo de adaptação. Há os intelectuais consoantes, ou seja, aqueles que "pertencem plenamente a uma sociedade, do jeito que ela é, que nela florescem sem um sentimento esmagador de dissonância ou dissidência" (SAID, 2000, p. 53-54).

Esses intelectuais aceitam a condição que a sociedade impõe, independente da opinião exposta. São figuras que procuram manter a harmonia e o equilíbrio como meios de sobrevivência a um lugar desconhecido. 
Assim, intelectuais consoantes são indivíduos acomodados e que não desenvolvem o papel perturbador do intelectual exposto por Said.

Mas existem os intelectuais que não se acomodam em relação ao novo lugar a que estão inseridos, que, de alguma forma, tentam elaborar meios para que possam agir perante os impasses que surgem na sociedade. $O$ intelectual moderno representa a não acomodação de um perfil, visto que o papel desses indivíduos não está ligado à aceitação das condições, mas à provocação das mesmas. Os intelectuais dissonantes são "indivíduos em conflito com a sua sociedade e, consequentemente, não acomodados e exilados no que diz respeito aos privilégios, ao poder e às honras" (SAID, 2000, p. 55).

Nesse quesito, encontra-se a figura que Graciliano desenvolveu dentro da sua trajetória no cárcere. Apesar de serem afastamentos diferentes, a não acomodação do escritor alagoano possibilitou, no período de isolamento, uma visão mais ampla da sociedade e, consequentemente, o desenvolvimento do seu percurso naquele contexto. Essa não acomodação refere-se ao fato de Graciliano iniciar suas anotações para que a prisão não o levasse a insanidade.

Assim, o exílio de Said e o emparedamento de Ramos foram fatores que, apesar dos contextos distintos, possibilitaram visões amplificadas das sociedades em que estavam inseridos e nas que foram obrigados, ou não a permanecerem.

\subsection{A CONDUTA}

Dentro do contexto intelectual, a conduta, certamente, é um dos fatores que mais pesam em relação à busca e ao fortalecimento da intelectualidade vigente no indivíduo em questão. $O$ objetivo é delinear a conduta do intelectual moderno exposta por Edward Said e ligá-la ao comportamento de Graciliano Ramos dentro de Memórias do Cárcere.

Para Said, a conduta do intelectual inicia-se com a afirmação de que o mesmo deve "ser um perturbador do status quo" (SAID, 2000, p. 13). Isso, consequentemente, está ligado ao mesmo comportamento do intelectual 
exílico: a não acomodação. $O$ intelectual vem com a missão de derrubar os modelos dominantes que regem uma sociedade. Tanto para Said quanto para Graciliano, a luta contra esses modelos dominantes se reflete em suas obras, as quais trazem uma imagem das experiências vividas por eles.

\subsection{1 - A vida e o engajamento como reflexos na obra literária}

Como esboçado na apresentação deste trabalho, a experiência de vida de Said mostra como a atividade intelectual que ele desenvolveu conseguiu derrubar os estereótipos que a sociedade criou em relação a ele. Ser considerado um dos maiores críticos literários do século $\mathrm{XX}$, certamente, não seria um título que Said teria recebido se este se acomodasse diante das imposições que viveu no exílio.

O conjunto de obras literárias de Said reflete bem essa conduta de intelectual moderno e engajado. Orientalismo, com certeza, foi um marco na carreira de Said, não só por representar o mundo oriental, em vários de seus aspectos, mas também por mostrar que a cultura árabe está inserida e fez parte da construção da cultura ocidental.

Quando escreveu Orientalismo, Edward Said pretendia mostrar o poder intelectual que esse nome carregava. Assim, as duas principais finalidades dessa escrita foram: "apresentar a genealogia intelectual de um modo que ainda não foi feito e criticar com a esperança de provocar debates" (SAID, 2007, p. 55-56). E, realmente, Said atingiu seu objetivo.

Por meio de sua obra e mesmo com inúmeras críticas positivas e negativas, Orientalismo foi sinônimo de discussão e reflexão, e ainda é. Dessa forma, Orientalismo constituiu-se como um dos exemplos de perturbação para as sociedades envolvidas.

Memórias do Cárcere também foi exemplo de perturbação, pois quando foi publicado, chocou uma sociedade que não estava preparada para ver ações que o governo escondia. E esse incômodo não aconteceu somente após a 
publicação do livro, mas durante as anotações de Ramos na cadeia e, também, no período em que Graciliano começou a escrever a obra.

Não somente Memórias do Cárcere, mas outras obras de Graciliano como, Vidas Secas, por exemplo, mostram a luta que Ramos travou em tentar elevar a voz daqueles que estavam esquecidos. A literatura de Ramos, igualmente a de Said, vem associada à suas experiências de vida, impossibilitando uma separação entre elas.

Além disso, as obras produzidas pelos dois mostram os ensejos que tinham em relação a ajudar, de alguma forma, os indivíduos que estavam carentes, necessitados de alguém que falassem por eles. Por isso, Said e Graciliano desenvolvem uma literatura voltada para os aspectos sociais, enaltecendo os pontos que refletiam mais problemas e que precisavam ser vistos. Na opinião de Graciliano, a literatura que se distancia da realidade:

Só se ocupa de coisas agradáveis, não se molha em dias de inverno e por isso ignora que há pessoas que não podem comprar capas de borracha, [...] acha que tudo está direito, que o Brasil é um conjunto e que somos felizes. (MORAES, 2012, p. 197)

No que se refere ao engajamento e às experiências de vida, Ramos e Said compartilham os mesmos ideais, visto que os dois manifestaram o papel de um intelectual que se preocupa e tenta disseminar ideias que podem salvar uma coletividade que está enfraquecida perante as opressões dos mais fortes.

\subsection{2 - A escrita como forma de sobrevivência}

O caminho de Graciliano Ramos dentro de Memórias do Cárcere baseiase basicamente em traçar um trajeto que fosse possível sobreviver ao período de limitações e, ao mesmo tempo, conseguir obter respostas para os problemas pelos quais estava inserido na época.

Quando um intelectual se vê preso a forças contrárias às suas, banido de sua sociedade, a primeira tentativa de reestabelecimento é a busca pela 
adaptação. Ramos soube escolher alternativas que, de alguma forma, trouxeram benefícios a ele como, de princípio, a aceitação da condição de que era um preso político. Assim, a consciência prudente que Ramos transpareceu o permitiu tentar seguir o lado que parecia mais favorável naquele momento.

A convicção da própria insuficiência nos leva a essas abstenções; um mínimo de honestidade nos afasta das empresas que não podemos realizar direito. Mas as circunstancias nos agarram, nos impõem deveres terríveis. Sem nenhuma preparação, ali me achava a embrenhar-me em dificuldades, prometendo mentalmente seguir o caminho que me parecia razoável. (RAMOS, 2008, p. 63)

Incomodar é sinônimo da atividade intelectual que Said delineia. Para mostrar isso em Graciliano, deve-se entender sua trajetória dentro do cárcere como homem e como narrador da história. Sua conduta carcerária não revelou um homem submisso, pelo contrário, o comportamento de Ramos está ligado à observação minuciosa dos fatos e das pessoas que o acompanhavam.

Para Ramos, sua estadia na prisão não significava vingança de alguém ou algo que representasse semelhança com desafronta, "o país ainda não chegara a tal grau de estupidez e malandragem" (RAMOS, 2008, p. 50). O fator que incomodava os primeiros momentos junto aos militares era o silêncio que pairava e a esperada acusação formal que não vinha.

"Nem uma palavra de acusação. Permaneceríamos talvez assim. Com certeza havia motivo para nos segregarem, mas aquele silêncio nos espantava" (RAMOS, 2008, p. 68). O intelectual sente-se perturbado com o silêncio, o qual influencia diretamente em sua conduta. A falta de acusação concreta e formal foi um dos fatores que aborreceram Ramos até sua morte, mas, ao mesmo tempo em que o incomodava, também o estimulava para que a história fosse contada.

O autoritarismo político consegue deturpar, de alguma forma, as cabeças pensantes que querem mudar a estrutura que rege o sistema. De tal modo, os intelectuais acomodados sentem-se de mãos atadas e não 
conseguem desenvolver um papel engajado que manifeste o objetivo da intelectualidade.

O primeiro índice da não acomodação de Graciliano dentro do cárcere foi a aceitação, inicialmente perturbadora, de começar suas anotações a respeito do período de isolamento. Escrever um livro dentro de um cárcere parecia algo instigante, mas ao mesmo tempo, incoerente. Manter-se disposto a anotar todas as suas ações e de seus companheiros era algo complexo, visto que a condição física de Graciliano e o cenário ao qual estava exposto eram avessos.

Assim, registrar todos os fatos que aconteciam dentro do cárcere foi a saída que Graciliano encontrou para não se acomodar perante a situação. $O$ fato é que, para um intelectual, torna-se condenável agregar-se às pessoas que acreditam e depositam sua confiança em "homens" superiores e neles esperam a restituição do conforto. O trabalho intelectual pede coragem e displicência ao mesmo tempo, visto que é muito mais simples o intelectual não se comprometer com as estruturas envolvidas no setor em que se encontra.

\footnotetext{
Por isso, na minha perspectiva, o principal dever do intelectual é a busca de uma independência relativa em face de tais pressões. Daí as minhas caracterizações do intelectual como exilado e marginal, como armador e como autor de uma linguagem que tenta falar a verdade ao poder." (SAID, 2000, p. 17)
}

As anotações de Ramos era uma forma de fazer justiça imediata e de lutar pela sobrevivência da não acomodação, visto que a probabilidade de conformismo diante da realidade imposta era grande. Para SAID (2000, p. 28), "não houve nenhuma grande revolução na história moderna sem intelectuais", não há como almejar mudanças sem querer e perceber que os intelectuais são necessários para a reformulação dos fatos os quais se revelam perturbadores a uma sociedade.

No momento em que Graciliano se indagava sobre os reais ensejos que o levou até ali, as únicas armas que estavam de prontidão eram os livros e as folhas de papel. Não havia como calcular uma forma estratégica para livrarem- 
se daquele meio, já que o campo o qual estavam inseridos era enigmático. A escrita manteve-se como o único meio em que Graciliano ainda permanecia ativo, já que os outros continuavam ausentes.

Além disso, Graciliano sentia-se incomodado pelo fato de estar "desocupado" durante o período de isolamento, sentia a necessidade de se manter pensante, ativo de alguma forma. Ramos via na escrita a possibilidade de ascensão dentro do contexto perturbador e inverossímil. "Enxergava na preguiça uma espécie de furto. Necessário escrever, narrar os acontecimentos em que me embaraçava" (RAMOS, 2008, p. 132).

É interessante notar que a escrita, para Graciliano Ramos, sempre foi uma forma de sobrevivência em sua vida. Na prisão, ela se desenvolveu como uma forma de evasão da realidade. Na vida fora do cárcere, a escrita representou ascensão financeira e desejos de mudanças sociais.

O intelectual tem a missão de buscar, de alguma forma, caminhos que possam proporcionar soluções rápidas e pertinentes para os imprevistos. A condição para que o intelectual moderno desenvolva essas alternativas é saber controlar o medo, mas não extingui-lo de sua caminhada, uma vez que é praticamente impossível viver uma vida intelectual sentindo-se completamente seguro.

Apesar da sensatez em relação a escolher o caminho mais apropriado, que suprisse suas maiores necessidades durante a prisão, Graciliano sentia-se confuso, buscando ideias que se misturavam com a complexidade da realidade imposta com a desejada.

Edward Said explica que isso acontece porque o intelectual que está afastado de sua sociedade fica numa espécie de meio termo, nunca está completamente integrado às novas condições, visto que o mundo fora do afastamento ainda o pertence. Assim, a nova realidade o confunde, fazendo com que ela, por vezes, se distorça.

$$
\begin{aligned}
& \text { O exilado existe num estado intermédio, nem } \\
& \text { completamente integrado no novo lugar, nem }
\end{aligned}
$$




$$
\begin{aligned}
& \text { totalmente liberto do antigo, rodeado de } \\
& \text { semienvolvimentos e semidistanciamentos, nostálgico } \\
& \text { e sentimentalista, por um lado, imitador competente ou } \\
& \text { proscrito em segredo, por outro. (SAID, 2000, p. 52) }
\end{aligned}
$$

Said também reforça que "nunca conseguimos chegar por completo à nova casa e estar em sintonia com ela ou com a nova situação." (SAID, 2000, p.55). Isso revela que, mesmo o intelectual aceitando sua nova posição, a adaptação nunca será totalizada. Esse fator implica a perturbação das ideias, fato comum em meio à desordem e ao ócio.

Ao começar a registrar os fatos que aconteciam nos primeiros períodos de prisão, Graciliano manteve-se cauteloso por questões óbvias, era um preso político e não queria se envolver em situações que o prejudicassem ainda mais e isso também aconteceu fora da prisão. As exposições públicas de Ramos eram sempre discretas e seus trabalhos refletiam essa discrição também. Por isso, além de não se considerar um representante da política, ele também tinha receio de que o governo the prendesse novamente.

Para Said, não é necessário que um intelectual se manifeste de forma espalhafatosa e divulgue seu trabalho à comunidade pertencente. $O$ trabalho intelectual não é uma espécie de propaganda que precisa ser vendida e admitida por um grande número de pessoas. $\mathrm{O}$ grande pensador age nas minúcias do sistema que lhe é imposto, abre pequenos atalhos para que, por um lado ou outro, consiga chegar a partes de seu objetivo, mantendo a discrição necessária que esse trabalho exige.

Aqui, também, fica clara a ligação que se pode fazer ao fato de Graciliano ter recusado divulgar as ideias do partido comunista em seus livros, principalmente em Memórias do Cárcere, pois o intelectual público age para o público, para seu auditório e não para satisfazer os planos de um partido político.

Se Graciliano procurasse planejar Memórias do Cárcere de acordo com os parâmetros que a sociedade embute como verdadeiros e convencionais ao mundo, certamente a obra não alcançaria o impacto de literatura engajada, 
com o alto poder crítico social que exerce, pois o poder de reflexão ficaria abafado por quesitos utópicos e ilusórios, fantasiados em meio à beleza que grandes romances oferecem.

Graciliano Ramos foi corajoso e original ao se manter exposto aos perigos que aquelas anotações the traziam e, principalmente, em dar continuidade à escrita após a prisão. A escrita era uma estratégia de sobrevivência no sentido figurado da palavra durante o período da prisão e no sentido literal durante a escrita na década de 40 .

Além disso, como apresentado no capítulo I, conservar as personagens tais como eram, com seus nomes e características reais poderia the trazer problemas, pois ele estava invadindo a privacidade delas, mas o livro não teria sentido se fosse moldado na estrutura de um romance. Os laços criados dentro da cadeia permitiram que, de fato, a história pudesse ser contada mais tarde.

\footnotetext{
O receio de cometer indiscrição exibindo em público pessoas que tiveram comigo convivência forçada já não me apoquenta. Muitos desses antigos companheiros distanciaram-se, apagaram-se. Outros permaneceram junto a mim, ou vão reaparecendo ao cabo de longa ausência, alteram-se, completam-se, avivam recordações meio confusas - e não vejo inconveniência em mostrá-los. (RAMOS, 2008, p. 13)
}

\subsection{3 - A liberdade da atividade intelectual}

O Estado Novo na década de 30 e todas as suas imposições que se estenderam até meados da década de 40 influenciaram diretamente na reprodução dos fatos que Graciliano descreveu em Memórias do Cárcere. Não somente o Estado Novo, mas os movimentos de esquerda também.

Graciliano soube dar voz a esse quadro opressor em que o Brasil estava exposto, não distorceu os fatos, pensamentos nem personagens. Manteve-se coerente a suas ideias, posicionando-se quando notava conveniente e 
satisfatório e, também, se afastava quando suas forças físicas ou mesmo sua raiva não permitiam sua imposição.

A conduta de um intelectual representativo deve posicionar-se como modelo de coragem e veracidade; consequentemente, a tranquilidade que os intelectuais passam às pessoas que se tornam enfraquecidas dentro de uma comunidade permite a esse indivíduo maior flexibilidade ao agir em relações aos fatos e pensamentos que regem um sistema. Com isso, a liberdade agrega-se aos valores intelectuais, os quais são disseminados a seus adeptos, formando assim um conjunto de princípios que regem a vida intelectual.

Ramos não tinha a intenção de agradar ninguém com seus escritos, planejá-los de maneira convencional; ele observou e analisou de maneira muito subjetiva e fiel à suas interpretações, não teve interesse em destacar alguém com objetivos de enaltecimento. Isso permite ao leitor que consiga, realmente, enxergar a veracidade dos acontecimentos que atravessam a obra Memórias do Cárcere.

Por isso, mesmo que sofrendo as pressões políticas na época da escrita do livro, Ramos manteve sua liberdade na hora de narrar os fatos e pôde expressar sua intelectualidade por meio deles.

\footnotetext{
Não me obrigo a reduzir um panorama, sujeitá-lo a dimensões regulares, atender ao paginador e ao horário do passageiro do bonde. Posso andar para a direita e para a esquerda como um vagabundo, determe longas paradas, saltar passagens desprovidas de interesse, passear, correr, voltar a lugares conhecidos. Omitirei acontecimentos essenciais ou mencioná-los-ei de relance, como se os enxergasse pelos vidros pequenos de um binóculo; ampliarei insignificâncias, repeti-las-ei até cansar, se isto me parecer conveniente. (RAMOS, 2008, p. 14)
}

O intelectual, por meio de suas ações, tem a missão de promover o conhecimento humano, instigando os indivíduos a refletirem sobre suas vidas e ao ambiente a que pertencem. Como conduta intelectual, o intelectivo não pode 
provocar a prisão de ideias, visto que isso leva à insuficiência do desenvolvimento dessa classe na sociedade.

Said destaca a importância de um intelectual agenciar o livre-arbítrio nos indivíduos que estão inseridos em seu meio, visto que essa é uma das incumbências mais importantes na busca da intelectualidade do indivíduo: provocar a liberdade (SAID, 2000, p. 32). Não somente das pessoas que o cercam, mas também a liberdade de ação e pensamento do próprio intelectual.

Graciliano procurou manter seus pensamentos e seus propósitos, mesmo dentro de um cenário completamente oposto a eles. Isso significava respeitar seus princípios sem se acomodar com as normas impostas pelo cárcere, pois, se as aceitasse, Ramos se tornaria mais um passivo em relação às decisões do governo.

Um exemplo bastante satisfatório nesse sentido aplica-se ao momento em que Graciliano chegou à Casa de Detenção no Rio de Janeiro e foi obrigado a preencher um formulário que indagava sobre sua religião. Ramos, não satisfeito com a pergunta, fez questão de deixar explícito que não era adepto de nenhuma crença. Isso, obviamente, chateou os agentes penitenciários, os quais queriam obrigar Graciliano a citar uma religião, já que era conveniente. Entretanto, Ramos não se dissipou de suas confianças e fez questão de expor que não era religioso.

Esse comportamento de Graciliano comprova a conduta do intelectual proposta por Edward Said, a qual visa não se acomodar perante as leis que a sociedade do isolamento propõe. Obviamente, o que se coloca em pauta é a coragem de Ramos por confrontar as normas, mas, também, deve-se destacar que, ao mesmo tempo em que há coragem, há também o risco que Graciliano corre.

O intelectual que está privado de sua liberdade, como é o caso de Ramos, sabe dar voz às questões que o incomodam e fazer dessas indagações um sistema que produz mudanças significativas a um meio, a um povo e ao próprio intelectual. 


\subsection{4 - A flexibilidade como busca do conhecimento}

Outra postura considerável que Graciliano adquiriu dentro do cárcere foi a flexibilidade que permitiu que ele, por vezes, se mantivesse sensato em meio à realidade confusa. Ramos não tinha outra escolha, ou se adaptava à situação, ou se tornaria um insano, à mercê do sistema.

A autoanálise que constantemente fazia de seus atos também o ajudou para que pudesse analisar o sofrimento alheio e o interpretar como seu. Isso, também, mostra um amadurecimento de Ramos dentro da narrativa, pois o narrador da década de 40 é bem mais sensível aos fatos do que o narrador que estava preso.

Essa autoanálise de Graciliano também está ligada às atitudes de seus companheiros e como o narrador lidava com isso, visto que, foi por meio desses homens e mulheres que Ramos descobriu seus pontos fracos e defeitos que o atrapalhavam na convivência dentro do cárcere.

Manter-se em crescente autoanálise significa, para um intelectual, permitir que outras pessoas, por meio de seu exemplo, possam dar continuidade a esse processo de atualização de pensamentos, mantendo-os em embasamentos flexíveis, capazes de não permitir a acomodação do indivíduo dentro de uma sociedade.

O exemplo de Miguel Batista dado no primeiro capítulo reforça essa ideia de reflexão por meio da autoanálise. A flexibilidade que o intelectual adota como conduta responsável pelo crescimento intelectivo, permite que esse indivíduo consiga desenvolver uma autonomia no meio em que está adentrado. Consequentemente, essa autonomia possibilita que o intelectual analise-se mediante essas construções.

Por conseguinte, a análise que Graciliano fez de si após o encontro com Miguel Batista mostra como um intelectual pode agir de maneira verdadeira perante si mesmo. Assim, além de contribuir para uma análise mais íntima, o intelectual é capaz de se julgar de acordo com seus princípios, visto que Graciliano conceituava-se ríspido demais em algumas ocasiões. 
Memórias do Cárcere representa 0 processo de busca pelo conhecimento que Graciliano Ramos, enquanto figura representativa, desenvolveu dentro do período de prisão. As atitudes tomadas dentro do cárcere, o pensamento conturbado, as barreiras da adaptação dentro do ambiente e seus registros do cotidiano miserável a que foi submetido exemplificam e esclarecem o quão particular e emaranhado torna-se a trajetória que leva ao desenvolvimento da intelectualidade e, consequentemente, ao conhecimento.

Se a língua era um dos pontos fortes que caracterizam Graciliano Ramos, seus registros são sinônimos de estratégia coerente com a conduta intelectual proposta por Edward Said. "Duas características essenciais da ação intelectual são: saber usar bem a língua e saber quando intervir através dela" (SAID, 2000, p. 33).

As anotações de Graciliano representaram o meio mais ágil de revirar o sistema que estava imposto a ele e aos outros indivíduos, produzindo efeito direto na conduta do escritor. Se o intelectual tem a missão de lutar ao lado dos mais fracos, daqueles que não têm representação (SAID, 2000, p. 35), Graciliano, mesmo debilitado fisicamente dentro do cárcere, conseguiu realizar isso por meio de seus escritos. E fora dele, toda a confecção da obra também teve a intencionalidade de denunciar e intervir a favor dos mais fracos que sofreram com as imposições da ditadura.

A condição física de Ramos foi outro fator que influenciou diretamente a conduta do escritor em alguns momentos dentro do exílio. Graciliano ao mesmo tempo em que usava a escrita como arma instantânea de sobrevivência não ocultou, por meio dela, os momentos em que se sentiu debilitado e entregue às condições do meio, mas que foi obrigado a se adaptar.

Não era a degradação moral que me oprimia [...]. me sentia humilhado, no atordoamento; não buscava saber se me restariam forças na alma dentro da realidade inconcebível. A alma fugia-me, na verdade, e inquietava-me adivinhar que a resistência física ia abandonar-me também, de um momento para outro: 
jogar-me-ia sobre as tábuas sujas, acabar-me-ia aos poucos, respirando amoníaco, envolto em pestilências. (RAMOS, 2008, p. 105)

O intelectual como figura representativa não sente necessidade de esconder suas debilidades físicas ou morais. Graciliano não se importou em esconder as dificuldades pelas quais passou naquela ocasião de caos; pelo contrário, sentiu necessidade de expô-las nos registros, mesmo após anos do acontecido. Distorcer sentimentos e ações não está ligada à conduta de um intelectual, já que ele preza pela verdade, independente se essa se mantém favorável ou não.

Contudo, Graciliano adaptou-se aos momentos de confusão mental associada com o painel angustiante, inóspito e destorcido que o cárcere apresentava, mantendo seus quesitos de sobrevivência: a escrita alinhada à observação das atitudes de seus companheiros.

A partir do momento em que Graciliano habituou-se à situação, a possibilidade de representar os indivíduos pertencentes aos emparedamentos de uma prisão autoritária, tornou-se mais adequada ao contexto em que estavam inseridos.

Para Edward Said, o intelectual tem que estar disposto a representar as vozes que estão enfraquecidas e que não conseguem manifestar-se em momentos de desordem, "em momentos difíceis, o intelectual é, muitas vezes, visto pelos seus compatriotas como aquele que representa, testemunha e fala em nome do sofrimento da nação" (SAID, 2000, p. 49).

Edward Said e Graciliano Ramos conseguiram, mesmo em cenários diferentes, levantar as vozes dos que estavam mudos perante as contradições que os atingiam.

A condição de Said em terras americanas a qual prevaleceu por proteger e colocar em destaque a questão palestina, bem como a busca pela sobrevivência dentro e fora do cárcere por Ramos mostram homens que não se conformaram diante da realidade e foram buscar meios de mudá-la. "Um 
intelectual é como um náufrago que, de certo modo, aprende a viver com a terra e não nela" (SAID, 2000, p. 59). 


\section{CONCLUSÃO}

Os intelectuais sempre foram atraentes objetos de estudos, visto que 0 exercício da intelectualidade é conturbador e, por vezes, contraditório; sendo assim, muitos escritores e críticos apresentam de modos diferentes a conduta intelectual, revelando ao público as várias visões que eles têm sobre ela.

Esse trabalho procurou mostrar as características que Said dispõe como figura intelectiva em suas obras e associá-las ao comportamento que Graciliano Ramos desenvolveu durante o período em que estava preso (emparedamento concreto) e no momento da escrita da obra (emparedamento simbólico).

Fica evidente que a imagem intelectual que Said exibe é bem marcada por questões históricas e sociais, permitindo que o leitor compreenda que a atividade intelectual exercida pelo indivíduo depende muito do contexto sociohistórico em que ele esteve ou está inserido. Além disso, Said apresenta um intelectual próximo da realidade, que está disposto a representar e se doar para que suas ideias sejam disseminadas a favor de um bem coletivo. Ainda assim, nem sempre, como Said explica, essa representação vai conseguir agradar a todos, pelo contrário; por vezes ela vai provocar a irritação da oposição, ou seja, daqueles que não estão em acordo com o papel crítico que o intelectual desempenha em uma sociedade.

Said também acredita que os intelectuais-escritores desempenham uma representação social mais exposta, já que esses fazem de seu trabalho um instrumento de levantamento, exibição e denúncia dos problemas que cercam uma comunidade.

Dessa forma, esses intelectuais apresentam-se de forma engajada, expondo seu ponto de vista e tentando convencer uma maioria de que nem sempre seguir imposições pré-estabelecidas é o melhor caminho para o desenvolvimento de uma sociedade. Assim, a figura de Graciliano Ramos no 
contexto de Memórias do Cárcere se faz muito condizente com essas características que Said expõe.

Como escritor, por meio de Memórias do cárcere, Graciliano conseguiu mostrar ao mundo os abusos e os desrespeitos que o governo opressor da época do Estado Novo cometeu com muitas pessoas que, aparentemente, mostravam certa oposição em relação às ideias do governo. O caráter engajado da obra permitiu que a sociedade literária brasileira reconhecesse Ramos com um autor crítico e exibidor das desigualdades que afetavam o Brasil na época.

Para fundamentar a hipótese de relação entre as ideias de Said e a desenvoltura de Graciliano Ramos em Memórias do cárcere, foi preciso analisar seu comportamento durante os meses em que ficou preso, desde o momento de sua prisão em Alagoas até a conquista de sua liberdade no Rio de Janeiro. Essa análise também incluiu alguns personagens que acompanharam a trajetória de Ramos no contexto da prisão e que foram essenciais para a adaptação e sobrevivência do mesmo no momento em que o desespero era maior que a sanidade.

Esses personagens, além de contribuírem de forma significativa para que Ramos pudesse contar em Memórias do cárcere as histórias que vivenciou na prisão, também colaboraram para que Graciliano tivesse uma evolução em alguns aspectos que foram expostos pelo próprio narrador e que confrontam posturas diferentes antes e durante o encarceramento. Os principais fatos que marcaram a vida de Graciliano Ramos após a saída da prisão também foram descritos, já que eles foram importantes para a construção da obra e análise do narrador.

Com essas pesquisas, pôde-se confirmar que algumas das ideias sobre a figura do intelectual que Said apresentou durante sua carreira literária configuram-se de forma plausível em Graciliano Ramos como, por exemplo, o engajamento por meio da obra literária, fazendo dela uma espécie de arma contra os problemas sociais e políticos; a exposição de suas ideias sem intenção de enaltecimento de algum nome ou opinião. 
Said e Ramos também apresentam a vida literária como uma resposta das experiências vividas por eles; a figura pública que os dois representaram como intelectuais, críticos, escritores e militantes não se separa da vida pessoal, ou seja, foram intelectuais que viveram para desempenhar de forma intensa seus ideais. Mesmo que esse desempenho fosse construído, paralelamente, aos impasses que surgem durante o desenvolvimento da atividade intelectual, como as questões sociais, políticas e históricas que permeiam essa classe.

O envolvimento em causas sociais também foram pontos de destaque entre Said e Ramos. Said espreitou e analisou modos de amenizar os problemas que atingiam a Palestina; Graciliano também refletiu em suas obras a visão que tinha dos mais oprimidos, como os 'esquecidos' do sertão, os trabalhadores e os presidiários do final da década de 30.

Edward Said e Graciliano Ramos aguçaram a intelectualidade; mesmo distanciados culturalmente, conseguiram criar discursos que foram capazes de gerar discussões acadêmicas e políticas. $E$ isso é a missão da literatura engajada, apresentar pontos que são críticos e fazer deles temas para reflexão e desenvolvimento, mesmo que essas discussões criem críticas negativas a seus autores. 


\section{REFERÊNCIAS BIBLIOGRÁFICAS}

- ABDALA JÚNIOR, Benjamin. Literatura Comparada e relações comunitárias hoje. São Paulo, Ateliê Editorial, 2012.

- AHMAD, Aijaz. Linhagens do presente - ensaios. São Paulo, Boitempo Editorial, 2002.

- BOBBIO, Norberto. Os intelectuais e o poder: dúvidas e opções dos homens de cultura na sociedade contemporânea. São Paulo: Editora UNESP, 2007.

- BOSI, Alfredo. Céu, inferno. São Paulo, Editora 34, 2003.

- BRUNACCI, Maria Izabel. Graciliano Ramos - um escritor personagem. Belo Horizonte, Autentica Editora, 2008.

- CHARLE, Christophe. Nascimento dos intelectuais contemporâneos. Trad. Maria Helena C. Bastos. História da Educação, ASPEHE/FaE/UFPel. Pelotas, n.14, p.141-156, Setembro, 2003.

- FERREIRA, Muniz Gonçalvez. O PCB e a organização do campo intelectual brasileiro. In: Intelectuais partidos: os comunistas e as mídias no Brasil. Rio de Janeiro, E-Papers, 2012. 
- FILHO, Waldemar S. Pedreira. Resenha bibliográfica. Revista de administração de empresas, vol. 17, no1, São Paulo, 1977. Disponível em http://www.scielo.br . Acesso em 02 de maio de 2015.

- GRAMSCI, Antonio. Os intelectuais e a Organização da Cultura. Editora Civilização Brasileira, 1982.

- MARQUEZINI, Fabiana Buitor Carelli. "Entre bichos e deuses: a ficcionalização das personagens em Jorge Amado e Graciliano Ramos". In Figuras de Ficção. Coimbra, 2006.

- MELLO, Mário Vieira de. Desenvolvimento e Cultura - O problema do esteticismo no Brasil. São Paulo, Nacional, 1963.

- MORAES, Dênis de. "Graciliano no fio da navalha: cooptação, engajamento e resistência". In Intelectuais partidos: os comunistas e as mídias no Brasil. Rio de Janeiro, E-Papers, 2012.

0 velho Graça - uma biografia de Graciliano Ramos. São Paulo, Boitempo, 2012.

- OLIVEIRA, Francisco de. Critica à razão dualista - 0 ornitorrinco. São Paulo, Boitempo Editorial, 2003. 
- RAMOS, Graciliano. Memórias do Cárcere. Rio de Janeiro, Record, 2008.

- SAID, Edward W. Humanismo e crítica democrática. São Paulo, Companhia das Letras, 2007b.

Orientalismo - o Oriente como invenção do Ocidente. São Paulo, Companhia das Letras, 2007a.

Representações do Intelectual - As palestras de Reith de 1993. Lisboa, Edições Colibri, 2000. 